\title{
Cochrane
}

Cochrane Database of Systematic Reviews

\section{Phacoemulsification with posterior chamber intraocular lens versus extracapsular cataract extraction (ECCE) with posterior chamber intraocular lens for age-related cataract (Review)}

de Silva SR, Riaz Y, Evans JR

de Silva SR, Riaz Y, Evans JR.

Phacoemulsification with posterior chamber intraocular lens versus extracapsular cataract extraction (ECCE) with posterior chamber intraocular lens for age-related cataract.

Cochrane Database of Systematic Reviews 2014, Issue 1. Art. No.: CD008812.

DOI: 10.1002/14651858.CD008812.pub2.

www.cochranelibrary.com

Phacoemulsification with posterior chamber intraocular lens versus extracapsular cataract extraction (ECCE) with posterior chamber intraocular lens for age-related cataract (Review) 
TABLE OF CONTENTS

HEADER

ABSTRACT

PLAIN LANGUAGE SUMMARY . . . . . . . . . . . . . . . . . . . . . . . . . . . . . . . . . . . . .

SUMMARY OF FINDINGS FOR THE MAIN COMPARISON . . . . . . . . . . . . . . . . . . . . . . . 3

BACKGROUND . . . . . . . . . . . . . . . . . . . . . . . . . . . . . . . . . . . . 6

Figure 1. . . . . . . . . . . . . . . . . . . . . . . . . . . . . . . . . . . . . . . . .

OBJECTIVES . . . . . . . . . . . . . . . . . . . . . . . . . . . . . . . . . . . . . .

METHODS . . . . . . . . . . . . . . . . . . . . . . . . . . . . . . . . . . . . . . 8

RESULTS . . . . . . . . . . . . . . . . . . . . . . . . . . . . . . . . . . . . . 10

Figure 2. . . . . . . . . . . . . . . . . . . . . . . . . . . . . . . . . . . . . . 11

Figure 3. . . . . . . . . . . . . . . . . . . . . . . . . . . . . . . . . . . . . . 12

Figure $4 . \quad$. . . . . . . . . . . . . . . . . . . . . . . . . . . . . . . . . . . . . 13

DISCUSSION . . . . . . . . . . . . . . . . . . . . . . . . . . . . . . . . . . . . . 16

AUTHORS' CONCLUSIONS . . . . . . . . . . . . . . . . . . . . . . . . . . . . . . . . 17

ACKNOWLEDGEMENTS . . . . . . . . . . . . . . . . . . . . . . . . . . . . . . . . . 17

REFERENCES . . . . . . . . . . . . . . . . . . . . . . . . . . . . . . . . . . . . . . 17

CHARACTERISTICS OF STUDIES . . . . . . . . . . . . . . . . . . . . . . . . . . . . . . . . . . . . . . .

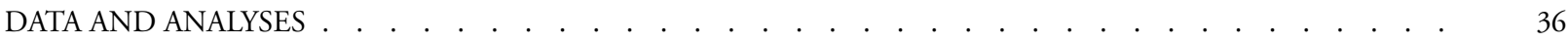

Analysis 1.1. Comparison 1 Phacoemulsification versus ECCE, Outcome 1 Good functional vision at 3 months (uncorrected acuity).

Analysis 1.2. Comparison 1 Phacoemulsification versus ECCE, Outcome 2 Good functional vision at 12 months (uncorrected acuity).

Analysis 1.3. Comparison 1 Phacoemulsification versus ECCE, Outcome 3 Good functional vision at 3 months (best corrected acuity).

Analysis 1.4. Comparison 1 Phacoemulsification versus ECCE, Outcome 4 Good functional vision at 12 months (best corrected acuity).

Analysis 1.5. Comparison 1 Phacoemulsification versus ECCE, Outcome 5 Poor visual outcome at 3 months (best corrected acuity $6 / 60$ or worse).

Analysis 1.6. Comparison 1 Phacoemulsification versus ECCE, Outcome 6 Poor visual outcome at 12 months (best corrected acuity $6 / 60$ or worse).

1.8. Comparison 1 Phacoemulsification versus ECCE, Outcome 8 \% corneal endothelial cell loss

Analysis 1.10. Comparison 1 Phacoemulsification versus ECCE, Outcome 10 Posterior capsule opacification. . . . . 43

Analysis 1.11. Comparison 1 Phacoemulsification versus ECCE, Outcome 11 Retinal detachment. . . . . . . . 43

Analysis 1.12. Comparison 1 Phacoemulsification versus ECCE, Outcome 12 Cystoid macular oedema. . . . . . . 44

Analysis 1.13. Comparison 1 Phacoemulsification versus ECCE, Outcome 13 Iris prolapse. . . . . . . . . . 44

ADDITIONAL TABLES . . . . . . . . . . . . . . . . . . . . . . . . . . . . . . . . . . . 45

APPENDICES . . . . . . . . . . . . . . . . . . . . . . . . . . . . . . . . . . . . . . . . . . . . . 47

CONTRIBUTIONS OF AUTHORS . . . . . . . . . . . . . . . . . . . . . . . . . . . . . . . . . . . . .

DECLARATIONS OF INTEREST . . . . . . . . . . . . . . . . . . . . . . . . . . . . . . . . . . . . . . . . . 52

SOURCES OF SUPPORT . . . . . . . . . . . . . . . . . . . . . . . . . . . . . . . . . . . . . . . . . . . . . . .

DIFFERENCES BETWEEN PROTOCOL AND REVIEW . . . . . . . . . . . . . . . . . . . . . . . . . . . . 53

NOTES . . . . . . . . . . . . . . . . . . . . . . . . . . . . . . . . . . . . . . . 53

INDEX TERMS . . . . . . . . . . . . . . . . . . . . . . . . . . . . . . . . . . . . 53

Phacoemulsification with posterior chamber intraocular lens versus extracapsular cataract extraction (ECCE) with posterior chamber intraocular lens for age-related cataract (Review)

Copyright $\odot 2014$ The Cochrane Collaboration. Published by John Wiley \& Sons, Ltd. 


\title{
[Intervention Review] \\ Phacoemulsification with posterior chamber intraocular lens versus extracapsular cataract extraction (ECCE) with posterior chamber intraocular lens for age-related cataract
}

\author{
Samantha R de Silva ${ }^{1}$, Yasmin Riaz ${ }^{1}$, Jennifer R Evans ${ }^{2}$ \\ ${ }^{1}$ Oxford Eye Hospital, Oxford, UK. ${ }^{2}$ Cochrane Eyes and Vision Group, ICEH, London School of Hygiene \& Tropical Medicine, \\ London, UK \\ Contact address: Jennifer R Evans, Cochrane Eyes and Vision Group, ICEH, London School of Hygiene \& Tropical Medicine, Keppel \\ Street, London, WC1E 7HT, UK. jennifer.evans@1shtm.ac.uk.
}

Editorial group: Cochrane Eyes and Vision Group.

Publication status and date: New, published in Issue 1, 2014.

Review content assessed as up-to-date: 13 May 2013.

Citation: de Silva SR, Riaz Y, Evans JR. Phacoemulsification with posterior chamber intraocular lens versus extracapsular cataract extraction (ECCE) with posterior chamber intraocular lens for age-related cataract. Cochrane Database of Systematic Reviews 2014, Issue 1. Art. No.: CD008812. DOI: 10.1002/14651858.CD008812.pub2.

Copyright (C) 2014 The Cochrane Collaboration. Published by John Wiley \& Sons, Ltd.

\begin{abstract}
A B S T R A C T
Background

Age-related cataract is one of the leading causes of blindness worldwide. Therefore, it is important to establish the most effective surgical technique for cataract surgery.
\end{abstract}

Objectives

The aim of this review is to examine the effects of two types of cataract surgery for age-related cataract: phacoemulsification and extracapsular cataract extraction (ECCE).

Search methods

We searched CENTRAL (which contains the Cochrane Eyes and Vision Group Trials Register) (The Cochrane Library 2013, Issue 4), Ovid MEDLINE, Ovid MEDLINE In-Process and Other Non-Indexed Citations, Ovid MEDLINE Daily, Ovid OLDMEDLINE (January 1946 to May 2013), EMBASE (January 1980 to May 2013), Latin American and Caribbean Literature on Health Sciences (LILACS) (January 1982 to May 2013), Web of Science Conference Proceedings Citation Index - Science (CPCI-S) (January 1970 to May 2013), the metaRegister of Controlled Trials ( $m$ RCT) (www.controlled-trials.com), ClinicalTrials.gov (www.clinicaltrials.gov) and the WHO International Clinical Trials Registry Platform (ICTRP) (www.who.int/ictrp/search/en). We did not use any date or language restrictions in the electronic searches for trials. We last searched the electronic databases on 13 May 2013.

\section{Selection criteria}

We included randomised controlled trials of phacoemulsification compared to ECCE for age-related cataract.

Data collection and analysis

Two authors independently selected and assessed all studies. We defined two primary outcomes: 'good functional vision' (presenting visual acuity of 6/12 or better) and 'poor visual outcome' (best corrected visual acuity of less than 6/60) at three and 12 months after surgery. We also collected data on intra and postoperative complications, and the cost of the procedures.

Phacoemulsification with posterior chamber intraocular lens versus extracapsular cataract extraction (ECCE) with posterior chamber intraocular lens for age-related cataract (Review)

Copyright $\odot 2014$ The Cochrane Collaboration. Published by John Wiley \& Sons, Ltd. 


\section{Main results}

We included 11 trials in this review with a total of 1228 participants, ranging from age 45 to 94 . The studies were generally at unclear risk of bias due to poorly reported trial methods. No study reported presenting visual acuity, so we report both uncorrected (UCVA) and best corrected visual acuity (BCVA). Studies varied in visual acuity assessment methods and time frames at which outcomes were reported. Participants in the phacoemulsification group were more likely to achieve UCVA of 6/12 or more at three months (risk ratio (RR) 1.81 , 95\% confidence interval (CI) 1.36 to 2.41, two studies, 492 participants) and one year (RR 1.99 , 95\% CI 1.45 to 2.73 , one study, 439 participants). People in the phacoemulsification group were also more likely to achieve BCVA of 6/12 or more at three months (RR 1.12, 95\% CI 1.03 to 1.22, four studies, 645 participants) and one year (RR 1.06, 95\% CI 0.99 to 1.14 , one study, 439 participants), but the difference between the two groups was smaller. No trials reported BCVA less than 6/60 but three trials reported BCVA worse than 6/9 and 6/18: there were fewer events of this outcome in the phacoemulsification group than the ECCE group at both the three-month (RR 0.33, 95\% CI 0.20 to 0.55, three studies, 604 participants) and 12-month time points (RR 0.62, 95\% CI 0.36 to 1.05 , one study, 439 participants). Three trials reported posterior capsule rupture: this occurred more commonly in the ECCE group than the phacoemulsification group but small numbers of events mean the true effect is uncertain (Peto odds ratio (OR) 0.56, 95\% CI 0.26 to 1.22 , three studies, 688 participants). Iris prolapse, cystoid macular oedema and posterior capsular opacification were also higher in the ECCE group than the phacoemulsification group. Phacoemulsification surgical costs were higher than ECCE in two studies. A third study reported similar costs for phacoemulsification and ECCE up to six weeks postoperatively, but following this time point ECCE incurred additional costs due to additional visits, spectacles and laser treatment to achieve a similar outcome.

\section{Authors' conclusions}

Removing cataract by phacoemulsification may result in a better visual acuity compared to ECCE, with a lower complication rate. The review is currently underpowered to detect differences for rarer outcomes, including poor visual outcome. The lower cost of ECCE may justify its use in a patient population where high-volume surgery is a priority, however, there are a lack of data comparing phacoemulsification and ECCE in lower-income settings.

\section{PLAIN LANGUAGE SUMMARY}

\section{Comparing two different techniques of removing cataracts}

Cataract is a clouding of the lens in the eye and is one of the leading causes of blindness worldwide. The only method of treatment for this condition is surgery to remove the opacified lens and to replace it with a new lens, usually made of plastic. There are various surgical techniques for removing the lens, and in this review we compare two of them: phacoemulsification and extracapsular cataract extraction (ECCE).

A search was performed of the literature in May 2013 for studies comparing the two techniques and 11 randomised controlled trials were identified which included a total of 1228 participants. These trials included participants with age-related cataract and were conducted in Europe, South America and the Far East. We evaluated these for any biases that may have affected the data, extracted data according to pre-determined criteria and performed analyses of the pooled data from all studies where possible.

There were few studies that reported outcomes which met our pre-defined criteria. The studies were generally at unclear risk of bias due to poorly reported trial methods and the overall quality of the evidence for different outcomes ranged from moderate to very low. Phacoemulsification gave superior results at both three and 12-month time points. Complications were higher in the ECCE group than the phacoemulsification group. However, two out of three studies that reported costs indicated that ECCE was cheaper than phacoemulsification.

In summary, on the basis of the few studies that reported outcomes that we could include in our analysis, visual outcomes were better with phacoemulsification and complications were lower with this technique. However, ECCE was cheaper and in lower income countries ECCE may therefore have a role in maximising the number of people that can be treated with limited resources.

Phacoemulsification with posterior chamber intraocular lens versus extracapsular cataract extraction (ECCE) with posterior chamber 


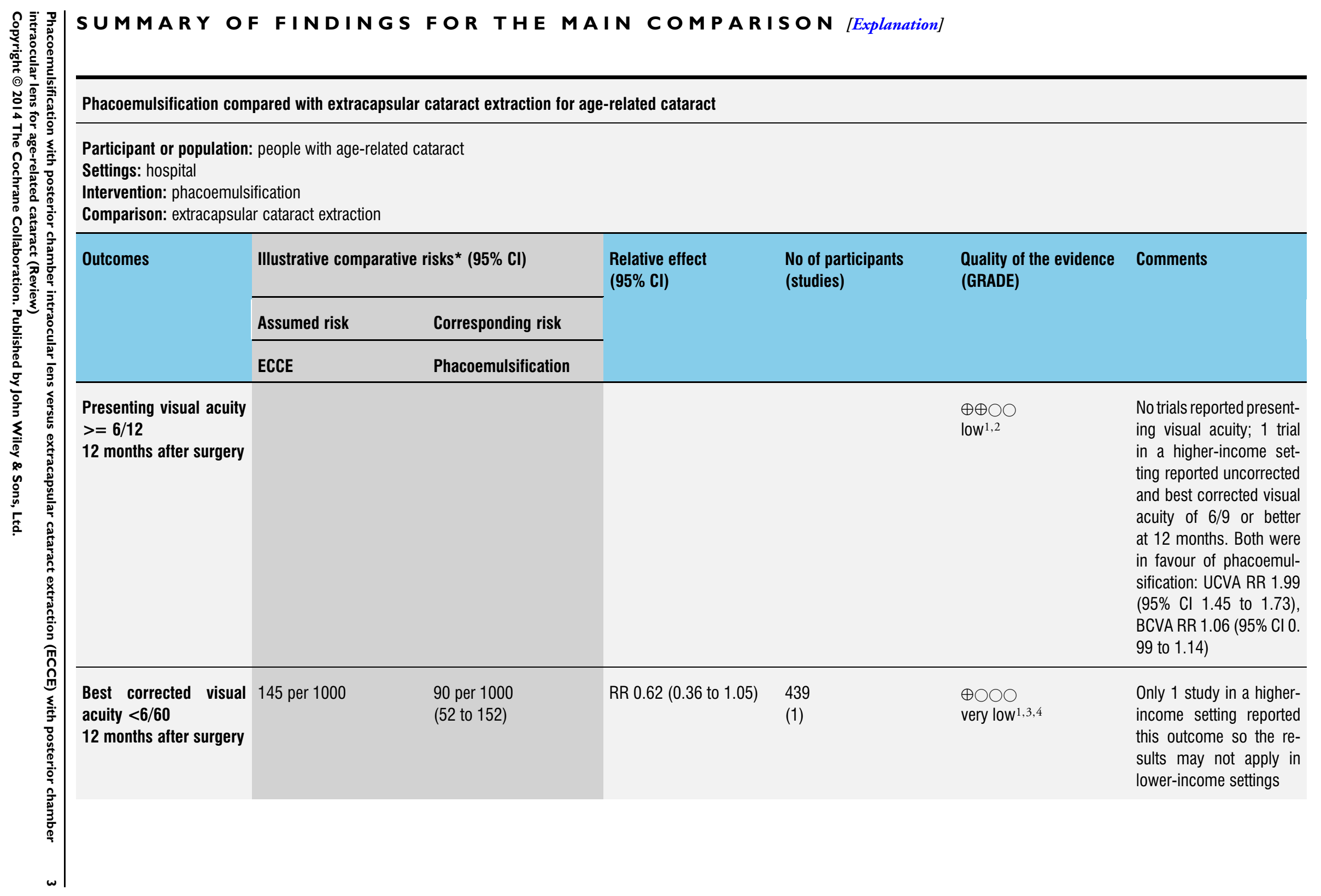




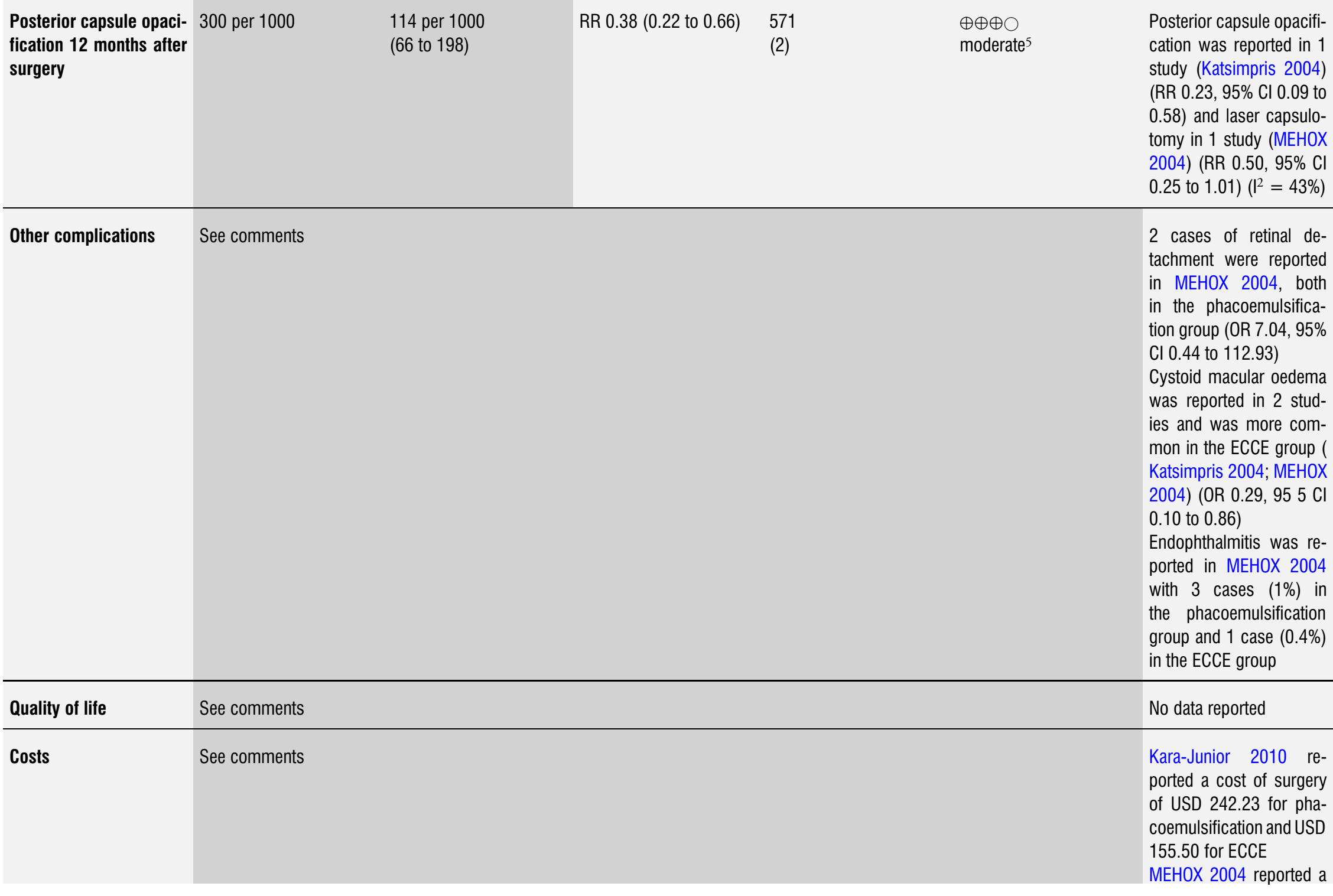


*The basis for the assumed risk (e.g. the median control group risk across studies) is provided in footnotes. The corresponding risk (and its $95 \%$ confidence interval) is based on the assumed risk in the comparison group and the relative effect of the intervention (and its $95 \% \mathrm{Cl}$ ).

CI: confidence interval; ECCE: extracapsular cataract extraction; RR: risk ratio; OR: odds ratio; UCVA: uncorrected visual acuity

GRADE Working Group grades of evidence

High quality: Further research is very unlikely to change our confidence in the estimate of effect.

Moderate quality: Further research is likely to have an important impact on our confidence in the estimate of effect and may change the estimate.

Low quality: Further research is very likely to have an important impact on our confidence in the estimate of effect and is likely to change the estimate.

Very low quality: We are very uncertain about the estimate.

Assumed risk estimated from control group risk across studies.

'Downgraded for inconsistency: only one study so we were not able to assess consistency.

2Downgraded for indirectness: no study reported presenting visual acuity.

${ }^{3}$ Downgraded for imprecision: wide confidence intervals, effect uncertain

${ }^{4}$ Downgraded for indirectness; cut-point $<6 / 9$ not $<6 / 60$.

Downgraded for indirectness: majority of events come from study that measured laser capsulotomy rather than posterior capsule

opacification. 


\section{B A C K G R O U N D}

\section{Description of the condition}

Cataract is the opacification of the normally transparent lens of the eye and occurs as a result of denaturation of lens proteins. This cloudiness can cause a decrease in vision and may lead to eventual blindness. Most cataracts are age-related. Initially, cataracts may not affect vision if the cataract remains small or at the periphery of the lens. If the cataract forms in the area of the lens directly behind the pupil, vision may be significantly impaired. Changes are not thought to be reversible and surgery is currently the only treatment option, where the cataract is removed and a replacement lens is inserted into the eye.

The World Health Organization (WHO) estimated from a recent global review of surveys that in 200237 million people worldwide were blind (Passolini 2004; Resnikoff 2004) and that age-related cataract remained the leading cause of blindness globally (as it was in 1990). Fifty per cent of world blindness is thought to be due to cataract and the majority of blinding cataract is found in developing countries. The contribution of cataracts to blindness globally is likely to grow due to an ageing population and unsuccessful attempts to control this blinding condition in low and middleincome countries .

Blindness and severe visual impairment have a significant impact on the socioeconomic development of individuals and societies. Cataract surgical treatment leads to substantial long-term savings in healthcare and social expenditure. Savings also accrue from the reduced commitment made by family members caring for a visually impaired person. Women have a significantly higher risk of cataract blindness or being visually impaired than men, mainly because of their higher incidence of cataract and inadequate access to eye health care, which is often provided preferentially to men (Lewallen 2002). The resulting downward socioeconomic spiral can be reversed through widely available, appropriate, costeffective and curative surgical interventions (Kuper 2008; Polack 2008; Polack 2010).

\section{Description of the intervention}

Phacoemulsification was first described in 1967 by Charles D. Kelman, an American ophthalmologist (1930-2004). It is the most commonly performed method of cataract extraction in the developed world. A small incision is made in the cornea (with a standard size of around $2.75 \mathrm{~mm}$, but may range from $2.2 \mathrm{~mm}$ to $3.2 \mathrm{~mm}$ ) and the crystalline lens is removed by ultrasonic fragmentation leaving the posterior lens capsule intact. This allows for a synthetic intraocular lens (IOL) to be inserted through the corneal incision into the capsular bag. The small incision allows rapid visual rehabilitation postoperatively and low induced astigmatism. This technique requires a phacoemulsification machine which may cost GBP 20,000 to 45,000 and the costs of required disposable equipment and maintenance are also high. Phacoemulsification requires extensive surgical training, particularly the necessity to carry out a continuous capsulorhexis.

Extracapsular cataract extraction (ECCE) was introduced with the development of microsurgical techniques in the early 1980s. The lens contents are removed through a large $12 \mathrm{~mm}$ incision leaving the posterior lens capsule intact. As with phacoemulsification, this keeps the anatomical barrier between the posterior and anterior segments of the eye intact and may reduce the risk of posterior segment complications. A posterior chamber IOL can then be placed in the capsular bag (Apple 1989; Duane 1986). If no IOL is implanted, aphakic glasses or contact lenses must be used.

Extracapsular surgery has been the preferred method of extraction in economically disadvantaged countries and most surgeons in developing countries have been trained to use this method. ECCE may result in more induced astigmatism in the short-term compared to phacoemulsification and a longer visual rehabilitation postoperatively. Patients who have had sutured ECCE will usually need to return to have the sutures removed in clinic, in order to achieve the best visual acuity. Further technological development has led to many surgeons in developing countries adopting sutureless ECCE surgery or manual small incision cataract surgery (MSICS).

Both sutured and sutureless ECCE leave in place the posterior capsule of the lens.

In the months or years after cataract surgery by either method a small percentage of people will develop a condition called posterior capsular thickening in which the capsule behind the new lens becomes opacified. This can be treated using laser treatment (YAG laser capsulotomy), in which a small opening is made in the back of the lens capsule, which restores vision.

Figure 1 is a flow diagram summarising the different types of cataract surgery.

Phacoemulsification with posterior chamber intraocular lens versus extracapsular cataract extraction (ECCE) with posterior chamber 


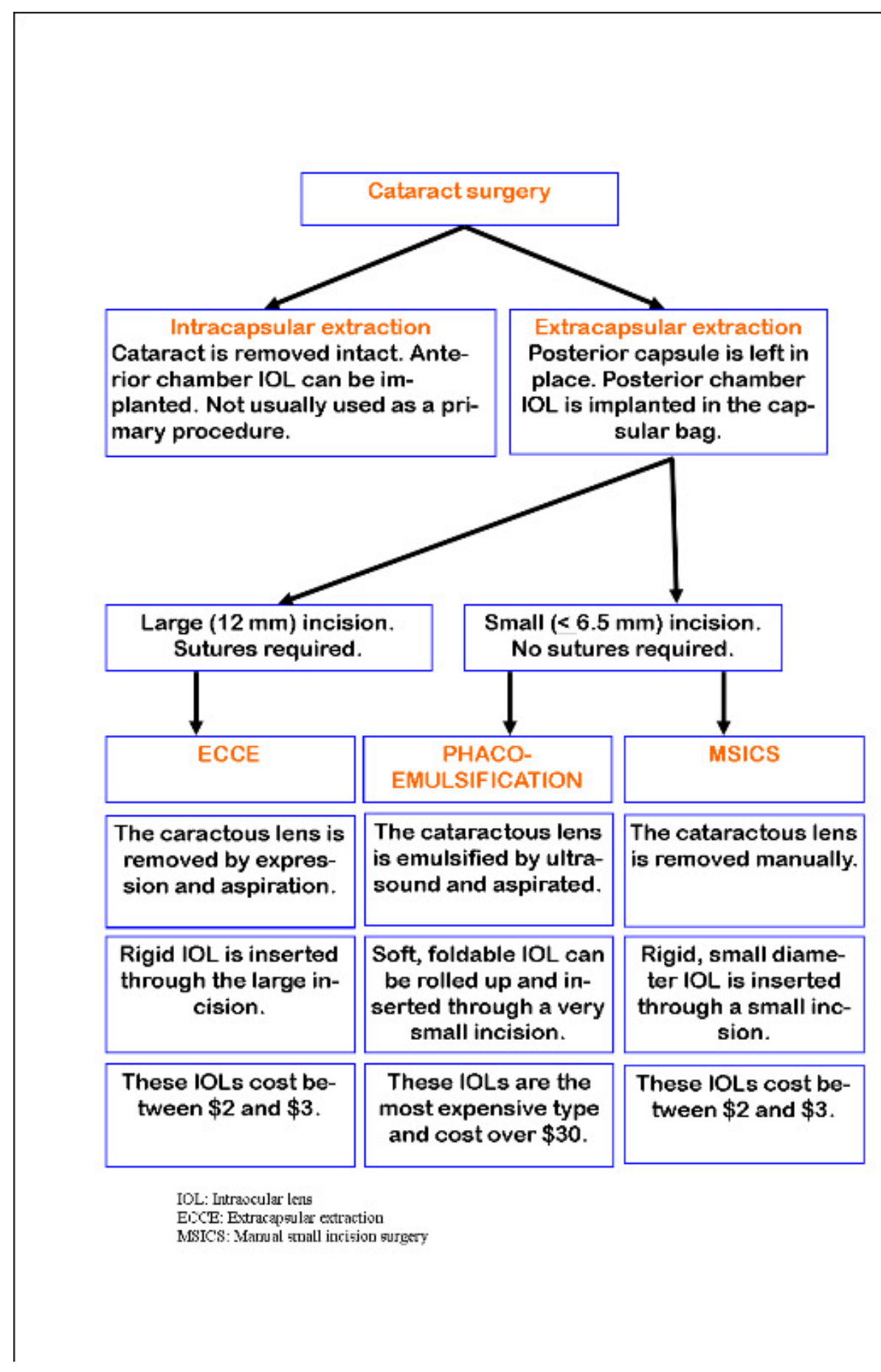

Phacoemulsification with posterior chamber intraocular lens versus extracapsular cataract extraction (ECCE) with posterior chamber 


\section{How the intervention might work}

Cataract surgery consists of removing the cloudy lens of the eye and replacing it with an artificial lens called an intraocular lens (IOL). Intraocular lenses can be made from a range of materials, and they can be made of varying size, shape and refracting power. Before cataract surgery the eye to be operated on is measured so that an IOL of the correct power (strength) can be inserted after the cataract has been removed. The IOL is usually placed inside the 'bag' of the lens capsule inside the eye. Other options for lens replacement include contact lenses and cataract glasses.

\section{Why it is important to do this review}

Although phacoemulsification is the most technologically advanced method for providing small incision, sutureless surgery it requires considerable resources in the form of the initial capital outlay for the phacoemulsification machine, and there are considerable ongoing costs due to consumables, maintenance and training of surgeons. It is the procedure of choice for cataract surgery in the Western world.

From a global perspective phacoemulsification is too costly for many developing countries where there is the highest incidence of cataract blindness. Manual small incision surgery and ECCE are alternative techniques available at a lower cost. A key question is whether the resources required for phacoemulsification are justified in a lower-income setting.

This review in its original form 'Surgical interventions for agerelated cataract' (Riaz 2006) compared the outcomes of different cataract surgical techniques. The techniques included initially were intracapsular extraction (ICCE), ECCE and phacoemulsification. In 2006 it was revised and a fourth surgical technique (MSICS) was added to the review.

Following consultation with the review authors and the Cochrane Eyes and Vision Group this update has been divided into three smaller reviews each using the same outcome measures but only comparing two surgical methods within each review. The ICCE technique is no longer included as this is method is no longer used as a primary procedure.

The cataract surgical techniques compared in these three reviews are:

1. ECCE and MSICS (Ang 2012);

2. phacoemulsification and ECCE (current review; published protocol Riaz 2010);

3. phacoemulsification and MSICS (Riaz 2013).
The aim of this review is to examine the effects of two types of cataract surgery: phacoemulsification and ECCE.

\section{METHODS}

\section{Criteria for considering studies for this review}

\section{Types of studies}

We included randomised controlled trials (RCTs) only in this review.

\section{Types of participants}

Participants in the trials were people with age-related cataract.

\section{Types of interventions}

We included trials that compared phacoemulsification with ECCE. With both interventions a posterior chamber IOL is implanted.

\section{Types of outcome measures}

\section{Primary outcomes}

Postoperative visual acuity

- Proportion of people achieving good functional vision defined as presenting* visual acuity better than or equal to $6 / 12$ in the operated eye.

- Proportion of people with a poor outcome after surgery defined as best corrected visual acuity (BCVA) worse than $6 / 60$ in the operated eye.

*Presenting visual acuity is vision that the person uses in normal life, i.e. with or without glasses, if worn.

\section{Secondary outcomes}

- Intraoperative complications

- capsular rupture with or without vitreous loss

- iris prolapse

- postoperative inflammation

$\circ$ other complications as reported

- Long-term complications (one year or more after surgery)

$\circ$ posterior capsule opacification

- retinal detachment

- glaucoma 
- cystoid macular oedema

- corneal endothelial cell loss

- corneal decompensation

other complications as reported

- Quality of life (self care, mobility, social and mental

function) as reported

- Cost

\section{Follow-up}

We measured outcomes at three months and one year after surgery. As studies may not have reported outcomes exactly at these time points we considered data collection within the following time periods:

- three months: from four weeks to three months;

- 12 months: from six months to less than 18 months.

\section{Search methods for identification of studies}

\section{Electronic searches}

We searched the Cochrane Central Register of Controlled Trials (CENTRAL) 2013, Issue 4, part of The Cochrane Library. www.thecochranelibrary.com (accessed 13 May 2013), Ovid MEDLINE, Ovid MEDLINE In-Process and Other Non-Indexed Citations, Ovid MEDLINE Daily, Ovid OLDMEDLINE (January 1946 to May 2013), EMBASE (January 1980 to May 2013), Latin American and Caribbean Health Sciences (LILACS) (January 1982 to May 2013), Web of Science Conference Proceedings Citation Index - Science (CPCIS) (January 1970 to May 2013), the metaRegister of Controlled Trials ( $m$ RCT) (www.controlled-trials.com), ClinicalTrials.gov ( www.clinicaltrials.gov) and the WHO International Clinical Trials Registry Platform (ICTRP) (www.who.int/ictrp/search/en). We did not use any date or language restrictions in the electronic searches for trials. We last searched the electronic databases on 13 May 2013.

See: Appendices for details of search strategies for CENTRAL (Appendix 1), MEDLINE (Appendix 2), EMBASE (Appendix 3), LILACS (Appendix 4), CPCI-S (Appendix 5), $m$ RCT (Appendix 6), ClinicalTrials.gov (Appendix 7) and the ICTRP (Appendix 8).

\section{Searching other resources}

We searched the reference lists of identified included studies. We contacted study authors and other experts in the field to identify unpublished studies or studies sent for publication or in press.

\section{Data collection and analysis}

\section{Selection of studies}

Two review authors independently screened the titles and abstracts resulting from the electronic searches. We removed duplicate records and obviously irrelevant titles and abstracts at this stage. We obtained full-text copies of any report referring to definitely or possibly relevant trials. We linked together multiple reports of the same study. We assessed these full-text reports for compliance of studies with eligibility criteria. We assessed trials meeting these criteria for risk of bias.

We documented all excluded studies that we obtained full-text copies of and provided a reason for exclusion.

\section{Data extraction and management}

We extracted data using a form developed by the Cochrane Eyes and Vision Group. Two authors extracted data and compared the results for differences. We resolved discrepancies by discussion. We initially addressed any disagreements which could not be resolved by contacting the study authors, and if this was unsuccessful we reported this in the review. Data were entered onto a spreadsheet, checked for accuracy by all study authors, and then cut and pasted into Review Manager (RevMan 2012).

\section{Assessment of risk of bias in included studies}

We assessed the risk of bias in each study using The Cochrane Collaboration's tool for assessing the risk of bias (Higgins 2011). We considered the following domains: sequence generation, allocation sequence concealment, masking (blinding), incomplete outcome data, selective outcome reporting and other potential sources of bias. We judged each bias domain as 'high risk of bias', 'low risk of bias' or 'unclear' (indicating either lack of information or uncertainty over the potential for bias). Two review authors independently assessed the risk of bias and disagreement was resolved by discussion. Authors were not masked to the report authors and trial results during the assessment.

\section{Measures of treatment effect}

The outcomes for this review were largely dichotomous (postoperative visual acuity and complications). Our measure of treatment effect was the risk ratio. For outcomes that occurred rarely (in less than $10 \%$ of the cohort), we used the Peto odds ratio. For continuous outcomes, such as the percentage of corneal endothelial cell loss, we used the mean difference.

\section{Unit of analysis issues}

The main unit of analysis issue was how the trial investigators dealt with two eyes. There were several options here: a trial may randomise people to the intervention groups and then apply the intervention and/or measure the outcome in one eye (study eye) 
or both eyes. However, if the intervention had been applied to both eyes, it would have been incorrect to analyse eyes without taking into account the fact that the eyes for a person are not independent. Alternatively a trial may randomly allocate eyes to an intervention so each person had a different intervention in each eye. In this case, the pairing would have to be taken into account in the analysis. In the protocol for this review, if the trial had been incorrectly analysed, we planned to contact the trial investigators for further information to enable calculation of a design effect (Perera 2007).

Although it was not always clearly reported, it is likely that people were randomised to treatment and data were reported for one (study) eye of each person in the studies included in this review.

\section{Dealing with missing data}

Our analyses are based on available data and assume that missing data are missing at random. We collected data on follow-up by treatment group and the reason for missingness, where available.

\section{Assessment of heterogeneity}

We assessed heterogeneity in several ways. Firstly, by documenting clinical and methodological differences between the studies. Secondly, by examining the forest plots to see whether the estimates of effect were consistent, and thirdly by considering the $\mathrm{I}^{2}$ statistic value and $\mathrm{Chi}^{2}$ test for heterogeneity (bearing in mind that the $\mathrm{Chi}^{2}$ test has low power when the number of trials is small).

\section{Assessment of reporting biases}

The main reporting biases that we considered were publication bias and outcome reporting bias. For publication bias, we planned to do a funnel plot to assess whether small trials had different effects, however there were not enough trials to carry this out. To assess outcome reporting bias we did a review outcome matrix using the ORBIT classification (Kirkham 2010).

\section{Data synthesis}

We analysed data from studies collecting comparable outcome measures with similar follow-up times using either the risk ratio, Peto odds ratio or mean difference as discussed above. Where it was appropriate to combine the results of different studies we pooled data using a random-effects model (unless there were three or fewer trials in which case we used a fixed-effect model).

The outcomes for this review included a number of complications. Initially we tabulated these data only. For outcomes that were commonly reported we went on to do a meta-analysis in order to provide a summary estimate of risk.

\section{Subgroup analysis and investigation of heterogeneity}

One potential source of heterogeneity was the length of follow-up. It is possible that visual outcome of surgery varies by length of follow-up - in particular with respect to posterior capsule opacification. In order to include as many trials as possible in the analyses we chose, a priori, a fairly broad follow-up period at 12 months (from six months to 18 months). If trials included in this review had very different follow-up periods, for example some at six months and some at 18 months, we planned to group them into three subgroups: six months, 12 months and 18 months, and allocated trials to these groups depending on when the majority of their participants were followed up. Currently there are not enough data included in the review to do this analysis.

\section{Sensitivity analysis}

If there were enough trials contributing to the meta-analyses we planned to investigate the effect of excluding poorer quality trials. In particular, we planned to investigate the effect of excluding trials where allocation concealment was not properly reported and where there was no masking of outcome assessment. However, there were not enough trials included to do this.

\section{RE S U L T S}

\section{Description of studies}

\section{Results of the search}

The electronic searches retrieved a total of 726 records (Figure 2). After deduplication we screened 570 records. We excluded 525 records as not relevant to the scope of the review. We obtained full-text copies of 45 records and have included 12 reports of 11 studies in the review (see Characteristics of included studies). We have excluded 31 studies (see Characteristics of excluded studies). Currently two studies are awaiting assessment as we are unable to obtain a translation of the papers and have been unsuccessful in contacting the authors to ask for assistance. If possible we will assess them at a further update.

Phacoemulsification with posterior chamber intraocular lens versus extracapsular cataract extraction (ECCE) with posterior chamber 
Figure 2. Study flow diagram.

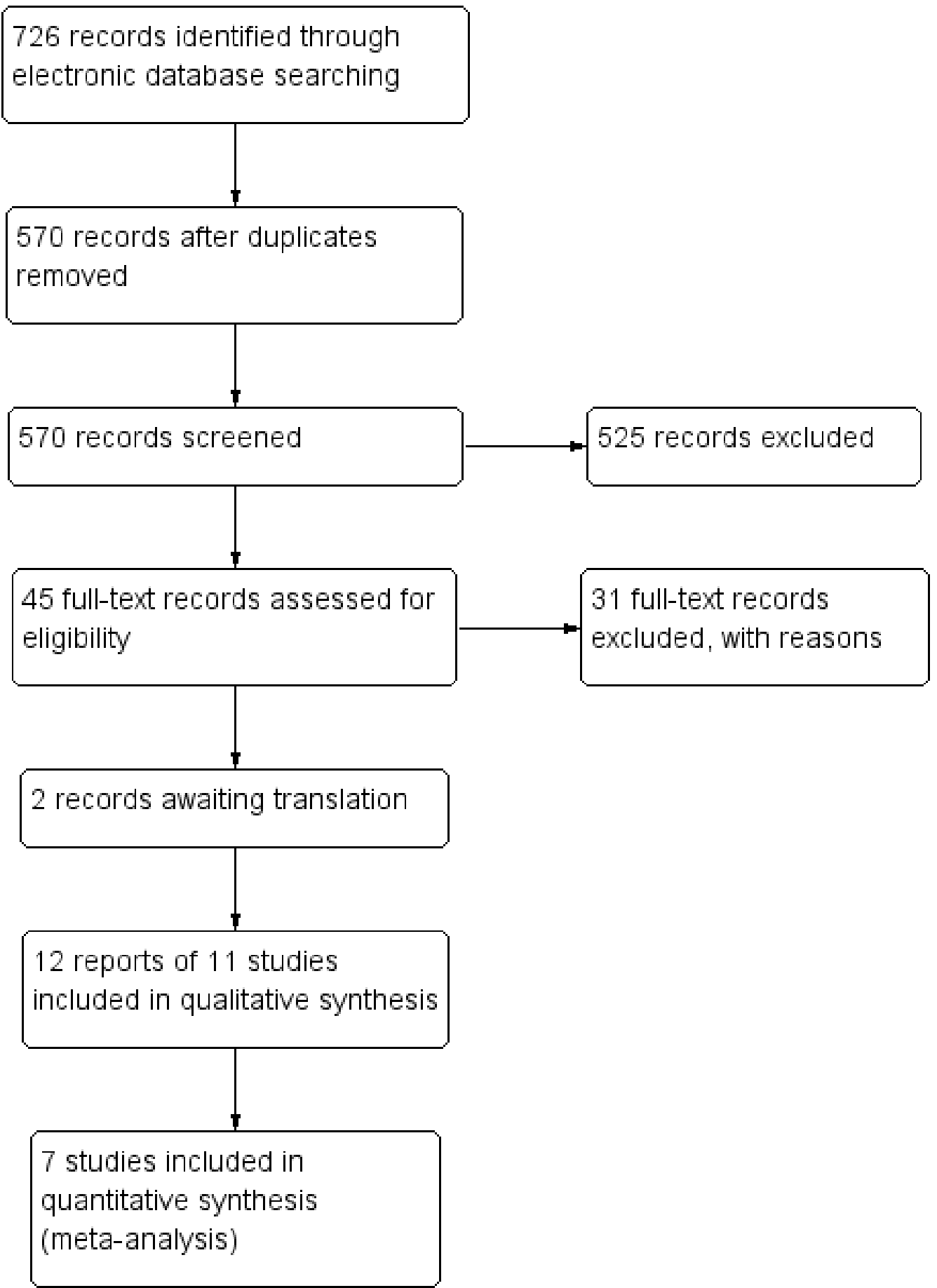




\section{Included studies}

We included 11 randomised controlled trials in this review (Chee 1999; Díaz-Valle 1998; George 2005; Kara-Junior 2010; Katsimpris 2004; Landau 1999; Laurell 1998; MEHOX 2004; Ravalico 1997; Rizal 2003; Stumpf 2006). See Characteristics of included studies.

A total of 1228 people were included in these studies: 34 (Chee 1999); 60 (Díaz-Valle 1998); 112 (George 2005); 205 (Kara-Junior 2010); 94 (Katsimpris 2004); 42 (Landau 1999); 42 (Laurell 1998); 500 (MEHOX 2004); 40 (Ravalico 1997); 60 (Rizal 2003) and 39 (Stumpf 2006). The age of the participants ranged from 45 to 94 years.

The studies were carried out in Brazil (Kara-Junior 2010; Stumpf 2006), Sweden (Landau 1999; Laurell 1998), Singapore (Chee 1999), Spain (Díaz-Valle 1998), India (George 2005), Greece ( Katsimpris 2004), the UK (MEHOX 2004), Italy (Ravalico 1997) and Malaysia (Rizal 2003).

Seven studies reported visual acuity outcomes (Chee 1999; George 2005; Katsimpris 2004; Laurell 1998; MEHOX 2004; Ravalico
1997; Stumpf 2006). However, data from four of these studies (Katsimpris 2004; Laurell 1998; Ravalico 1997; Stumpf 2006) were not in a suitable format for use in our analysis. Postoperative endothelial cell loss was reported in four studies (Díaz-Valle 1998; George 2005; Ravalico 1997; Stumpf 2006); postoperative inflammation in two studies (Chee 1999; Laurell 1998); surgically induced astigmatism in two studies (George 2005; MEHOX 2004); cost of surgery in three studies (Kara-Junior 2010; MEHOX 2004; Rizal 2003) and intraocular lens (IOL) haptic position in one study (Landau 1999).

Follow-up ranged from 30 days (Ravalico 1997) to two years ( Laurell 1998).

\section{Excluded studies}

We excluded 31 studies: see Characteristics of excluded studies for reasons for exclusion.

\section{Risk of bias in included studies}

See Figure 3; Figure 4 and individual 'Risk of bias' tables.

Figure 3. 'Risk of bias' graph: review authors' judgements about each risk of bias item presented as percentages across all included studies.

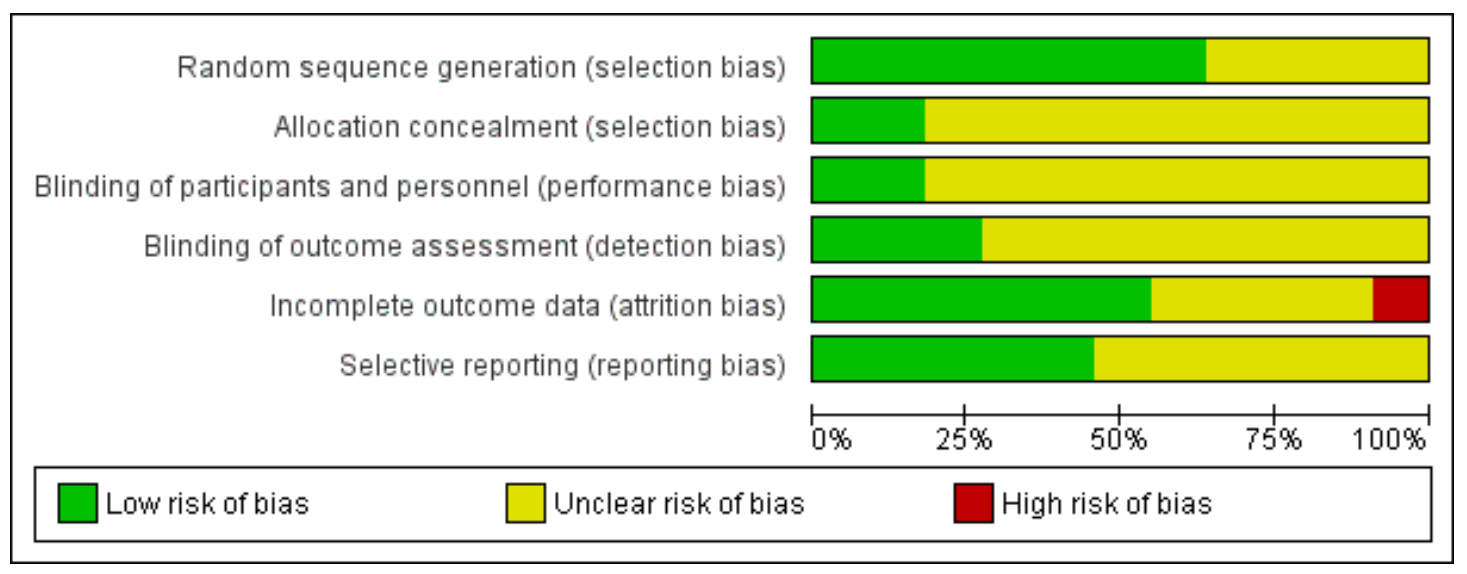

Phacoemulsification with posterior chamber intraocular lens versus extracapsular cataract extraction (ECCE) with posterior chamber 
Figure 4. 'Risk of bias' summary: review authors' judgements about each risk of bias item for each included study.

\begin{tabular}{|c|c|c|c|c|c|c|}
\hline & 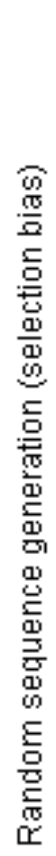 & 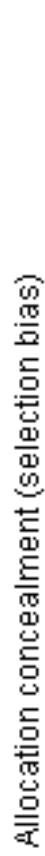 & 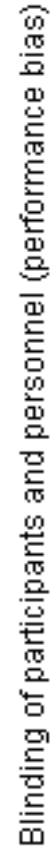 & 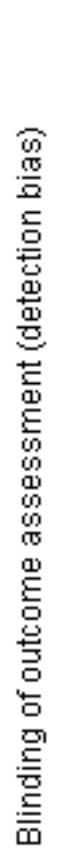 & 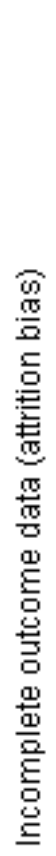 & 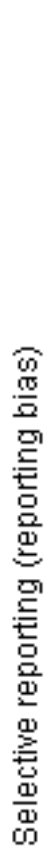 \\
\hline Chee 1999 & $?$ & $?$ & $?$ & $?$ & & \\
\hline Díaz-Valle 1998 & $?$ & $?$ & $?$ & $?$ & + & $?$ \\
\hline George 2005 & + & $?$ & $?$ & $?$ & $?$ & \\
\hline Kara-Junior 2010 & $?$ & $?$ & $?$ & $?$ & $?$ & $?$ \\
\hline Katsimpris 2004 & $?$ & $?$ & $?$ & $?$ & & \\
\hline Landau 1999 & & $?$ & + & & & \\
\hline Laurell 1998 & & & $?$ & + & & $?$ \\
\hline MEHOX 2004 & & + & + & + & $?$ & + \\
\hline Ravalico 1997 & & $?$ & $?$ & $?$ & + & $?$ \\
\hline Rizal 2003 & & $?$ & $?$ & $?$ & $?$ & $?$ \\
\hline Stumpf 2006 & & $?$ & $?$ & $?$ & + & $?$ \\
\hline
\end{tabular}

Phacoemulsification with posterior chamber intraocular lens versus extracapsular cataract extraction (ECCE) with posterior chamber 


\section{Allocation}

Seven trials clearly stated how participants were allocated to each arm of the study: four trials described computer-generated randomisation (George 2005; Landau 1999; Laurell 1998; Rizal 2003), one study used sequentially numbered opaque envelopes (MEHOX 2004), one study randomisation numbers (Ravalico 1997) and one study used ballots (Stumpf 2006). Four trials did not state the method of randomisation (Chee 1999; Díaz-Valle 1998; Kara-Junior 2010; Katsimpris 2004).

Allocation concealment was only clearly described in two studies (Laurell 1998; MEHOX 2004).

\section{Blinding}

\section{Performance bias}

Three studies reported masking of participants as to the nature of surgery (Landau 1999; Laurell 1998; MEHOX 2004). Eight studies did not comment.

\section{Detection bias}

Four studies reported that postoperative assessors were masked as to the nature of surgery (George 2005; Landau 1999; Laurell 1998; MEHOX 2004). However, obvious differences in postoperative appearance of the eye in each group may have influenced the ability to mask assessors effectively. Seven studies did not state whether assessors were masked as to the surgical technique.

\section{Incomplete outcome data}

Follow-up rates were variable between the included studies: $83 \%$ (Landau 1999), 88\% (MEHOX 2004), 90\% (George 2005), 95\% (Laurell 1998), and two studies had $100 \%$ follow-up rates (Ravalico 1997; Stumpf 2006). Five studies did not state whether any participants were lost to follow-up or did not complete the study period (Chee 1999; Díaz-Valle 1998; Kara-Junior 2010; Katsimpris 2004; Rizal 2003). Three studies (Landau 1999; Laurell 1998; MEHOX 2004) stated the reason for attrition.

\section{Selective reporting}

There were no obvious omissions in reporting results in the included studies. Several papers did not report on visual acuity outcomes or complications, however these were not defined outcomes in these studies. Formal assessment of the potential for selective outcome reporting bias using the ORBIT classification (Kirkham 2010) suggested that most non-reporting was low risk of bias (Table 1; Appendix 9).

\section{Other potential sources of bias}

Bias may be introduced into a study if the surgeon or surgeons were not equally experienced in each surgical technique and the groups are unbalanced with respect to surgeon. Four studies stated that surgeons were adequately experienced (George 2005; Kara-Junior 2010; Landau 1999; MEHOX 2004). The remainder of the studies did not comment on the level of surgical experience. In six studies, both surgical techniques were performed by a single surgeon (Díaz-Valle 1998; Katsimpris 2004; Landau 1999; Laurell 1998; Ravalico 1997; Stumpf 2006) and, with the exception of Landau 1999 , it is not stated whether the surgeon had equal experience of both techniques.

\section{Effects of interventions}

See: Summary of findings for the main comparison

\section{Primary outcomes}

The primary visual acuity outcomes for this review were presenting visual acuity of $6 / 12$ or better ("good functional vision"), or a best corrected visual acuity of worse than 6/60 ("poor visual outcome"). None of the papers documented presenting visual acuity, and therefore we report both uncorrected and best corrected visual acuity. Three out of seven papers that reported visual acuity did not state outcomes in a suitable format to include in our analysis.

\section{Good functional vision}

\section{Uncorrected visual acuity}

Chee 1999 reported UCVA of 6/12 or better at two months: this was achieved by $15 / 18$ participants in the phacoemulsification group and $8 / 16$ participants in the ECCE group (risk ratio (RR) $1.67,95 \%$ confidence interval (CI) 0.98 to 2.84). MEHOX 2004 reported UCVA of $6 / 9$ or better at three months: this was achieved by $83 / 237$ (35\%) phacoemulsification participants and $42 / 221$ (19\%) ECCE participants (RR 1.84, 95\% CI 1.33 to 2.54 ). The pooled risk ratio was 1.81 (95\% CI 1.36 to 2.41) (Analysis 1.1). Only one study (MEHOX 2004) reported UCVA of 6/9 or better at the 12 -month time point: this was achieved by $87 / 224(39 \%)$ participants in the phacoemulsification group and 42/215 (20\%) in the ECCE group (RR 1.99, 95\% CI 1.45 to 2.73) (Analysis $1.2)$.

Phacoemulsification with posterior chamber intraocular lens versus extracapsular cataract extraction (ECCE) with posterior chamber 


\section{Best corrected visual acuity}

Four trials reported best corrected visual acuity of $6 / 12$ or better at three months (Analysis 1.3) and one study at 12 months ( Analysis 1.4). At three months there was a small benefit in favour of phacoemulsification (pooled RR 1.12, 95\% CI 1.03 to 1.22). At 12 months the effect was smaller and uncertain (pooled RR $1.06,95 \%$ CI 0.99 to 1.14$)$.

\section{Poor visual outcome}

Poor visual acuity was reported in two trials with a lower incidence of poor BCVA in the phacoemulsification group (RR 0.33 , $95 \%$ CI 0.20 to 0.55 ) (Analysis 1.5 ). In the George 2005 study a visual acuity of worse than $6 / 18$ at six weeks was reported in $0 /$ 60 phacoemulsification participants and 5/52 ECCE participants (RR $0.08,95 \%$ CI 0.0 to 1.4). In the MEHOX 2004 study, visual acuity worse than $6 / 9$ was reported at three months in 17/237 phacoemulsification participants and 44/221 ECCE participants (RR 0.36, (95\% CI 0.21 to 0.61).

At 12 months, BCVA worse than 6/9 was reported by MEHOX 2004 in 20/244 phacoemulsification participants and 31/215 ECCE participants (RR 0.62, 95\% CI 0.36 to 1.05) (Analysis 1.6).

\section{Additional visual outcome data}

These studies included visual acuity data that were not in a suitable format for inclusion in our analysis.

Ravalico 1997 reported mean corrected decimal visual acuity at 30 days after surgery in the phacoemulsification group of 0.95 $+/-0.11$ and the ECCE group of $0.92+/-0.10$ (P value nonsignificant).

Stumpf 2006 reported an average corrected visual acuity at one, three and six months postoperatively. At the one and three-month time points, mean BCVA was better in the phacoemulsification group. The average decimal visual acuity was 0.83 in the phacoemulsification group and 0.68 in the ECCE group $(\mathrm{P}=0.02)$ at one month and it was 0.86 in the phacoemulsification group versus 0.77 in the ECCE group $(\mathrm{P}=0.04)$ at three months. However, at six months there was no significant difference between the two groups (0.87 in the phacoemulsification group, 0.81 in the ECCE group, $\mathrm{P}=0.35)$.

Katsimpris 2004 reported BCVA as mean $\log$ MAR at 14 months and found a better average BCVA in the phacoemulsification group (0.3 logMAR units) compared to the ECCE group (0.5 $\log$ MAR units).

\section{Secondary outcomes}

\section{Intraoperative complications}

Posterior capsular rupture was reported in three studies (George 2005; Katsimpris 2004; MEHOX 2004) (Analysis 1.7). The overall rate was lower in the phacoemulsification group: 10/353 (2.8\%) versus $17 / 335$ (5.1\%) in the ECCE group (Peto odds ratio (OR) $0.56,95 \%$ CI 0.26 to 1.22 ). In most papers only a few events were reported, with the exception of Katsimpris 2004, however this is likely to reflect the nature of pseudoexfoliative cataracts in this study, which are recognised to have a higher surgical complication rate.

Iris prolapse was reported in only the MEHOX 2004 study, with a rate of $0 / 246$ cases in the phacoemulsification group and 17/236 cases in the ECCE group (Peto OR 0.12, 95\% CI 0.05 to 0.32 ). Other intraoperative complications are tabulated here: Analysis 1.9.

\section{Postoperative complications}

Posterior capsule opacification was reported in two studies ( Katsimpris 2004; MEHOX 2004) (Analysis 1.10) at 12 to 14 months with an overall rate of $17 / 292(5.8 \%)$ in the phacoemulsification group and 40/279 (14.3\%) in the ECCE group (Peto OR $0.38,95 \%$ CI 0.22 to 0.66 ).

Retinal detachment was reported by MEHOX 2004 in 2/245 phacoemulsification cases and 0/232 ECCE cases (Peto OR 7.04, 95\% CI 0.44 to 112.93 ) (Analysis 1.11).

Cystoid macular oedema was reported in two studies (Katsimpris 2004; MEHOX 2004) with an overall rate of $3 / 292$ in the phacoemulsification group and 11/279 in the ECCE group (Peto OR $0.29,95 \%$ CI 0.10 to 0.86 ) (Analysis 1.12 ).

Corneal endothelial cell loss was reported in four studies, however the data from Ravalico 1997 were not included in our analysis, since it could not be compared to other studies. Overall there was no significant difference between the two techniques in terms of percentage of endothelial cell loss (mean difference 1.00, 95\% CI -0.88 to 2.89 ) (Table 2; Analysis 1.8 ).

Endophthalmitis rates were reported in only the MEHOX 2004 study with rates of $3 / 245(1 \%)$ in the phacoemulsification group and $1 / 232(0.4 \%)$ in the ECCE group.

Other complications are tabulated here: Analysis 1.14.

\section{Quality of life}

None of the studies reported quality of life.

\section{Cost}

Three studies reported the cost of cataract surgery in Brazil (KaraJunior 2010), the UK (MEHOX 2004) and Malaysia (Rizal 2003).

- Kara-Junior 2010 reported a cost of surgery of USD 242.23 for phacoemulsification and USD 155.50 for ECCE.

- MEHOX 2004 reported a cost of GBP 359.89 for phacoemulsification and GBP 367.57 for ECCE. Costs for phacoemulsification and ECCE were similar up to six weeks

Phacoemulsification with posterior chamber intraocular lens versus extracapsular cataract extraction (ECCE) with posterior chamber 
postoperatively, but following this time point ECCE incurred additional costs due to additional visits, spectacles and laser treatment to achieve a similar outcome.

- Rizal 2003 reported a cost of MYR 1978 for phacoemulsification and MYR 1664.46 for ECCE.

\section{DISCUSSION}

\section{Summary of main results}

The results are summarised in Summary of findings for the main comparison.

Our primary defined outcome was presenting visual acuity of $6 / 12$ or better, and since no study reported this directly we report both uncorrected and best corrected visual acuity. Only four studies reported this outcome: at both the three-month and 12-month time point phacoemulsification gave superior results to ECCE both in terms of uncorrected and best corrected visual acuity, although for best corrected acuity the size of the effect was small.

We defined poor visual outcome as BCVA of less than 6/60: the three papers that included poor BCVA data reported worse than $6 / 9$ and 6/18. The number of events in each group was small, making it difficult to draw conclusions. However, there were fewer events in the phacoemulsification group than the ECCE group at both the three-month (risk ratio $0.33,95 \% \mathrm{CI} 0.20$ to 0.55 ) and 12 -month time points (risk ratio $0.62,95 \%$ CI 0.36 to 1.05 ).

Regarding complication rates, the three papers stated posterior capsule rupture rates (PCR). This was higher in the ECCE group than the phacoemulsification group, however these results may be skewed by the high complication rate in the Katsimpris 2004 paper which only included complicated cataracts in participants with pseudoexfoliation. If this paper is excluded from analysis, the PCR rates for the two techniques are approximately equal.

The rates of iris prolapse, cystoid macular oedema and posterior capsular opacification were also higher in the ECCE group than the phacoemulsification group. Regarding other complications, the event rate was too low to draw definite conclusions regarding the superiority of one technique over another.

Phacoemulsification surgical costs were higher than ECCE in two studies (Kara-Junior 2010; Rizal 2003). MEHOX 2004 reported similar costs for phacoemulsification and ECCE up to six weeks postoperatively, but following this time point ECCE incurred additional costs due to additional visits, spectacles and laser treatment to achieve a similar outcome. Therefore the overall cost of phacoemulsification was slightly lower than ECCE in this study.

\section{Overall completeness and applicability of evidence}

Collation of evidence from all studies was difficult, due to varying methods of outcome reporting. For example visual acuity was documented in seven studies as Snellen, mean logMAR and mean decimal visual acuity, which were measured at varying time points. There were relatively small numbers of events across all studies regarding complications and therefore it is difficult to draw overall conclusions. The severity of cataract varied across studies, with some studies only including hard or pseudoexfoliative cataracts, and others excluding these more complicated cataracts. This makes it difficult to apply the results regarding complication rates to all levels of difficulty of cataract surgery.

The 11 included studies were carried out in nine countries, ranging from teaching hospitals in developed countries to high-volume cataract centres in developing countries. Therefore the results from this review may be applicable to multiple settings.

\section{Quality of the evidence}

All studies included in this review were randomised controlled trials. The quality of evidence, however, was low or very low, and this was due to inconsistency of reporting outcome data. Due to the slow postoperative recovery of visual acuity with ECCE surgery, long-term visual outcome data are especially important when comparing phacoemulsification to ECCE. Comparing visual outcome data between these two techniques at a time point earlier than three months may therefore have limited value. Despite four studies having a follow-up period of 12 months or longer, there were few data on long-term visual outcomes and complications such as posterior capsule opacification in these studies.

\section{Potential biases in the review process}

No obvious biases were identified in the review process.

\section{Agreements and disagreements with other studies or reviews}

A study carried out in Pakistan found $80 \%$ of phacoemulsification and $54 \%$ of ECCE participants had a postoperative unaided visual acuity of $6 / 12$ or better three months after surgery, and this trend is consistent with our results (Nangrejo 2011). A recent retrospective review of complications arising from 20,438 cases of phacoemulsification and 5736 cases of ECCE found a complication rate of $1.11 \%$ in the phacoemulsification group and $2.6 \%$ in the ECCE group. There were no statistically significant differences in the rate of endophthalmitis between the surgical techniques (Haripriya 2012). These findings are consistent with those of this review. 


\section{AUTHORS' CONCLUSIONS}

\section{Implications for practice}

There was some evidence from one study that uncorrected visual acuity outcomes were better in the phacoemulsification group 12 months after surgery. Only four studies were incorporated into our analysis of visual acuity at up to 3 or 12 months, but data in three other included papers (which were not included in the analysis due to the method of recording visual acuity) supported these findings. Regarding complications, the numbers of events were small, however there appears to be a higher rate of posterior capsule rupture and also posterior capsule opacification in the ECCE group compared to the phacoemulsification group. It is difficult to determine a difference regarding other complications due to the low numbers involved.

Overall, phacoemulsification appears to give better visual outcomes and fewer complications than ECCE. The lower cost of ECCE in two out of three studies may favour ECCE where resources are limited. However, a greater number of outpatient postoperative visits associated with the ECCE group may indirectly increase the costs of this technique, as shown in the MEHOX 2004 study.

\section{Implications for research}

Future studies need to have standardised reporting of outcomes enabling data from different studies to be pooled, in particular a precise and reproducible method of reporting visual acuity. In the absence of a formal core outcome set for such trials, we suggest that the primary outcomes we have included in this review (presenting Snellen visual acuity $6 / 12$ or better and best corrected visual acuity worse than 6/60) should be reported as a minimum. Future trials should also collect information on vision-related quality of life and cost utility. It should also be clearly stated whether one eye was operated on per participant or both eyes, and whether this decision was made prior to observing the outcome, as this may introduce bias.

Most of the trials included in this review had a relatively short follow-up period. We recommend a longer follow-up period, ideally 12 months or more. We recognise that this may be difficult in some populations but it is important especially with regard to complications such as posterior capsule opacification which may become visually significant over a longer time course.

\section{ACKNOW LEDGEMENTS}

The Cochrane Eyes and Vision Group (CEVG) created and executed the electronic searches. We thank Clare Gilbert, Catey Bunce, Daniel Gore and Richard Wormald for their comments on the protocol and/or review and Anupa Shah for editorial support. We would also like to thank Aeesha Malik for her work on the published protocol and earlier drafts of the review.

Richard Wormald (Co-ordinating Editor for CEVG) acknowledges financial support for his CEVG research sessions from the Department of Health through the award made by the National Institute for Health Research to Moorfields Eye Hospital NHS Foundation Trust and UCL Institute of Ophthalmology for a Specialist Biomedical Research Centre for Ophthalmology. The views expressed in this publication are those of the authors and not necessarily those of the Department of Health.

\section{R E F E R E N C E S}

\section{References to studies included in this review}

Chee 1999 \{published data only\}

Chee SP, Ti SE, Sivakumar M, Tan DT. Postoperative inflammation: extracapsular cataract extraction versus phacoemulsification. Journal of Cataract and Refractive Surgery 1999;25(9):1280-5.

Díaz-Valle 1998 \{published data only\}

Díaz-Valle D, Benítez del Castillo Sánchez JM, Castillo A, Sayagués O, Moriche M. Endothelial damage with cataract surgery techniques. Journal of Cataract and Refractive Surgery 1998;24(7):951-5.

George 2005 \{published data only\}

George R, Rupauliha P, Sripriya AV, Rajesh PS, Vahan PV, Praveen S. Comparison of endothelial cell loss and surgically induced astigmatism following conventional extracapsular cataract surgery, manual small-incision surgery and phacoemulsification. Ophthalmic Epidemiology 2005; 12(5):293-7.

Kara-Junior 2010 \{published data only\}

Kara-Junior N, Sirtoli MG, Santhiago MR, Parede TR, Espíndola RF, Carvalho Rde S. Phacoemulsification versus extracapsular extraction: governmental costs. Clinics 2010; 65(4):357-61.

Katsimpris 2004 \{published data only\} Katsimpris JM, Petropoulos IK, Apostolakis K, Feretis D. Comparing phacoemulsification and extracapsular cataract extraction in eyes with pseudoexfoliation syndrome, small pupil, and phacodonesis. Klinische Monatsblätter für Augenheilkunde 2004;221(5):328-33.

Landau 1999 \{published data only\} Landau IM, Laurell CG. Ultrasound biomicroscopy examination of intraocular lens haptic position after phacoemulsification with continuous curvilinear 
capsulorhexis and extracapsular cataract extraction with linear capsulotomy. Acta Ophthalmologica Scandinavica 1999;77(4):394-6.

\section{Laurell 1998 \{published data only\}}

Laurell CG, Zetterstrom C, Philipson B, Syren-Nordqvist S. Randomized study of the blood-aqueous barrier reaction after phacoemulsification and extracapsular cataract extraction. Acta Ophthalmologica Scandinavica 1998;76(5): $573-8$.

MEHOX 2004 \{published data only\}

Bourne RR, Minassian DC, Dart JK, Rosen P, Kaushal $S$, Wingate N. Effect of cataract surgery on the corneal endothelium: modern phacoemulsification compared with extracapsular cataract surgery. Ophthalmology 2004;111(4): 679-85.

Minassian DC, Rosen P, Dart JKG, Reidy A, Desai P, Sidhu M. Extracapsular cataract extraction compared with small incision surgery by phacoemulsification: a randomised trial. British Journal of Ophthalmology 2001;85(7):822-9.

Ravalico 1997 \{published data only\}

Ravalico G, Tognetto D, Palomba MA, Lovisato A, Baccara F. Corneal endothelial function after extracapsular cataract extraction and phacoemulsification. Journal of Cataract and Refractive Surgery 1997;23(7):1000-5.

Rizal 2003 \{published data only\}

Rizal AM, Aljunid SM, Normalina M, Hanom AF, Chuah $\mathrm{KL}$, Suzainah Y, et al. Cost analysis of cataract surgery with intraocular lens implantation: a single blind randomised clinical trial comparing extracapsular cataract extraction and phacoemulsification. Medical Journal of Malaysia 2003;58 (3):380-6.

Stumpf 2006 \{published data only\} Stumpf S, Nosé W. Endothelial damage after planned extracapsular cataract extraction and phacoemulsification of hard cataracts. Arquivos Brasileiros de Oftalmologia 2006;69 (4):491-6.

\section{References to studies excluded from this review}

Arriaga 2002 \{published data only\}

Arriaga ME, Lozono J. A comparative study of visual acuity outcomes: phacoemulsification vs extracapsular cataract extraction. Investigative Ophthalmology and Visual Science 2002;43:E-Abstract 360.

Balent 2001 \{published data only\}

Balent LC, Narendrum K, Patel S, Kar S, Patterson DA. High volume sutureless intraocular lens surgery in a rural eye camp in India. Ophthalmic Surgery and Lasers 2001;32 (6):446-55.

Bellucci 1995 \{published data only\}

Bellucci R, Morselli S, Pucci V. Small pupils: An indication of phacoemulsification. European Journal of Implant and Refractive Surgery 1995;7(4):236-9.

Bömer 1995 \{published data only\} Bömer TG, Lagrèze WD, Funk J. Increased intraocular pressure after cataract extraction--effect of surgical technique, surgical procedure and preventive drug administration. A prospective, randomized double-blind study. Klinische Monatsblätter für Augenheilkunde 1995;206 (1):13-9.

Bovet 1992 \{published data only\}

Bovet J, Stepanian E, Leuenberger PM. Phacoemulsification: technical initiation at what price?. Klinische Monatsblätter für Augenheilkunde 1992;200(5):447-50.

Bovet 1994 \{published data only\}

Bovet J, Baumgartner JM. Benefits of ambulatory surgery in cataract surgery. Klinische Monatsblätter für Augenheilkunde 1994;204(5):282-5.

Cavallini 1996 \{published data only\} Cavallini GM, Lugli N, Campi L, Lazzerini A, Longanesi L. Surgically induced astigmatism after manual extracapsular cataract extraction or after phacoemulsification procedure. European Journal of Ophthalmology 1996;6(3):257-63.

Dam-Johansen 1993 \{published data only\} Dam-Johansen M, Olsen T. Refractive results after phacoemulsification and ECCE: A comparative study. Acta Ophthalmologica 1993;71(3):382-7.

Dowler 2000 \{published data only\} Dowler JG, Hykin PG, Hamilton AM. Phacoemulsification versus extracapsular cataract extraction in patients with diabetes. Ophthalmology 2000;107(3):457-62.

Egger 1994 \{published data only\} Egger SF, Huber-Spitzy V, Skorpik C, Weghaupt H, Scholda C, Arocker-Mettinger E, et al. Different techniques of extracapsular cataract extraction: Bacterial contamination during surgery. Prospective study on 230 consecutive patients. Graefe's Archive for Clinical and Experimental Ophthalmology 1994;232(5):308-11.

Geerling 2000 \{published data only\} Geerling G, Dart JK. Management and outcome of cataract surgery in ocular cicatricial pemphigoid. Graefés Archive for Clinical and Experimental Ophthalmology 2000;238(2): 112-8.

Grinbaum 2003 \{published data only\} Grinbaum A, Blumenthal M, Assia E. Comparison of intraocular pressure profiles during cataract surgery by phacoemulsification and extracapsular cataract extraction. Ophthalmic Surgery, Lasers and Imaging 2003;34(3):182-6.

Honda 1995 \{published data only\} Honda K. Quality of vision in pseudophakic persons after extracapsular cataract extraction or phacoemulsificationaspiration. Japanese Journal of Clinical Ophthalmology 1995; 49(4):763-6.

\section{Kim 1996 \{published data only\}}

Kim JW. Comparative study of intraocular pressure change after cataract surgery: phacoemulsification and extracapsular cataract extraction. Korean Journal of Ophthalmology 1996; 10(2):104-8.

Lagreze 1996 \{published data only\} Lagreze WD, Bomer TG, Funk J. Effect of surgical technique on the increase in intraocular pressure after

Phacoemulsification with posterior chamber intraocular lens versus extracapsular cataract extraction (ECCE) with posterior chamber 
cataract extraction. Ophthalmic Surgery and Lasers 1996;27 (3):169-73.

\section{Li 2005 \{published data only\}}

Li Y, Wang CY, Wu LA, Ni W, Zhang L, Yang XG.

Early clinical research on tear film stability changes after surgery for age-related cataract. International Journal of Ophthalmology 2005;5(4):677-80.

Liu 1995 \{published data only\}

Liu Y, Li S. Reduction of induced corneal astigmatism after IOL implantation by small incision technique. Eye Science 1995;11(4):202-4.

Liu 2003a \{published data only\}

Liu J, Xu J, He M. Comparing patients' vision function after phacoemulsification with intraocular lens implantation with that after extracapsular cataract extraction with intraocular lens implantation. Chinese Journal of Clinical Rehabilitation 2003;7(1):30-1.

Liu 2003b \{published data only\} Liu JW, Xu JJ, He MG. Comparing patients' quality of life after phacoemulsification with intraocular lens implantation with that after extracapsular cataract extraction with intraocular lens implantation. Chinese Journal of Ophthalmology 2003;39(2):94-7.

Loo 2004 \{published data only\} Loo CY, Kandiah M, Arumugam G, Goh PP, John E, Gurusami B, et al. Cost efficiency and cost effectiveness of cataract surgery at the Malaysian Ministry of Health ophthalmic services. International Ophthalmology 2004;25 (2):81-7.

Lupidi 1994 \{published data only\}

Lupidi G, Diotallevi A, Tomassoni I, Feraudo M, Checcucci M, Mancinelli G. Postoperative astigmatism after phacoemulsification and ECCE. Annali di Ottalmologia e Clinica Oculistica 1994;120(10):593-7.

Ma 2000 \{published data only\}

$\mathrm{Ma} \mathrm{X}, \mathrm{Li}$ J, Wang J. Investigation on the results of posterior chamber intraocular lens implantation after different operative methods for diabetic patients. Chinese Ophthalmic Research 2000;18(4):364-6.

Matheu 1997 \{published data only\}

Matheu A, Castilla M, Duch F, Martí M, Lillo J, Gil M. Manual nucleofragmentation and endothelial cell loss. Journal of Cataract and Refractive Surgery 1997;23(7):995-9.

Moulick 2009 \{published data only\}

Moulick PS, Rodrigues FE, Shyamsundar K.

Evaluation of posterior capsular opacification following phacoemulsification, extracapsular and small incision cataract surgery. Medical Journal Armed Forces India 2009; 65(3):225-8.

Müller-Jensen 1996 \{published data only\} Müller-Jensen K, Barlinn B, Zimmerman H. Astigmatism reduction: No-stitch $4.0 \mathrm{~mm}$ versus sutured $12.0 \mathrm{~mm}$ clear corneal incisions. Journal of Cataract and Refractive Surgery 1996;22(8):1108-12.
Muralikrishnan 2004 \{published data only\}

Muralikrishnan R, Venkatesh R, Venkatesh Prajna N, Frick $\mathrm{KD}$. Economic cost of cataract surgery procedures in an established eye care centre in Southern India. Ophthalmic Epidemiology 2004;11(5):369-80.

Okinami 1994 \{published data only\} Okinami S, Hiroishi G, Saitou I, Iwaki M, Ogino N, Matsumura $\mathrm{M}$, et al. Intraocular lens implantation in eyes with uveitis. Japanese Journal of Clinical Ophthalmology 1994;48(4):739-44.

Ram 2001 \{published data only\} Ram J, Pandey SK, Apple DJ, Werner L, Brar GS, Singh R, et al. Effect of in-the-bag intraocular lens fixation on the prevention of posterior capsule opacification. Journal of Cataract and Refractive Surgery 2001;27(7):1039-46.

Sun 2010 \{published data only\} Sun XY, Li YZ, Qian T. Correction of corneal astigmatism by topography-guided incision in cataract surgery. International Journal of Ophthalmology 2010;10(3):462-5.

Watson 1992 \{published data only\} Watson A, Sunderraj P. Comparison of small-incision phacoemulsification with standard extracapsular cataract surgery: Postoperative astigmatism and visual recovery. Eye 1992;6(6):626-9.

\section{Yasuyoshi 1995 \{published data only\}}

Yasuyoshi H, Yokotani K, Miki M. Progression of diabetic retinopathy following different procedures of cataract surgery. Japanese Journal of Clinical Ophthalmology 1995;49 (12):1795-8.

\section{References to studies awaiting assessment}

\section{Durovic 2004 \{published data only\}}

Durovic BM. Endothelial trauma in the surgery of cataract [Trauma endotela kod hirurskog lecenja katarakte]. Vojnosanitetski Pregled 2004;61(5):491-7.

Trnavec 1997 \{published data only\}

Trnavec B, Cuvala J, Cernák A, Vodrázková E. Comparison of corneal endothelial cells after ECCE and phacoemulsification of the lens [Porovnanie nálezu endoteliálnych buniek rohovky po ECCE a fakoemulzifikácii sosovky]. Ceská a Slovenská Oftalmologie 1997;53(4):240-3.

\section{Additional references}

\section{Ang 2012}

Ang M, Evans JR, Mehta JS. Manual small incision cataract surgery (MSICS) with posterior chamber intraocular lens versus extracapsular cataract extraction (ECCE) with posterior chamber intraocular lens for age-related cataract. Cochrane Database of Systematic Reviews 2012, Issue 4. [DOI: 10.1002/14651858.CD008811.pub2]

\section{Apple 1989}

Apple DH, Marmalis N, Olson RJ, Kincaid MC. Intraocular Lenses: Evolution, Designs, Complications, and Pathology. Baltimore: Williams \& Wilkins, 1989.

Phacoemulsification with posterior chamber intraocular lens versus extracapsular cataract extraction (ECCE) with posterior chamber 


\section{Duane 1986}

Duane T. Textbook of Ophthalmology. Lippincott-Raven, 1986.

\section{Glanville 2006}

Glanville JM, Lefebvre C, Miles JN, Camosso-Stefinovic J. How to identify randomized controlled trials in MEDLINE: ten years on. Journal of the Medical Library Association 2006; 94(2):130-6.

\section{Haripriya 2012}

Haripriya A, Chang DF, Reena M, Shekhar M. Complication rates of phacoemulsification and manual small-incision cataract surgery at Aravind Eye Hospital. Journal of Cataract and Refractive Surgery 2012;38(8): 1360-9.

\section{Higgins 2011}

Higgins JPT, Altman DG, Sterne JAC (editors). Chapter 8: Assessing risk of bias in included studies. In: Higgins JPT, Green S (editors). Cochrane Handbook for Systematic Reviews of Interventions Version 5.1.0 (updated March 2011). The Cochrane Collaboration, 2011. Available from www.cochrane-handbook.org.

\section{Kirkham 2010}

Kirkham JJ, Dwan KM, Altman DG, Gamble C, Dodd S, Smyth R, et al. The impact of outcome reporting bias in randomised controlled trials on a cohort of systematic reviews. BMJ 2010;340:c365.

\section{Kuper 2008}

Kuper H, Polack S, Eusebio C, Mathenge W, Wadud Z, Foster A. A case-control study to assess the relationship between poverty and visual impairment from cataract in Kenya, the Philippines, and Bangladesh. PLoS Medicine 2008;5(12):e244.

Lewallen 2002

Lewallen S, Courtright P. Gender and use of cataract surgical services in developing countries. Bulletin of the World Health Organization 2002;80(4):300-3.

\section{Nangrejo 2011}

Nangrejo KM, Sahto AA, Pechuho MA, Siddiqui SJ, Abbassi AM. Visual outcome, phacoemulsification versus extracapsular cataract extraction. Medical Channel 2011;17 (3):29-31.

Passolini 2004

Passolini D, Mariotti SP, Pokharel GP, Pararajasegarm R, Etyalale D, Negrel AD, et al. 2002 global update of available data on visual impairment:a compilation of populationbased prevalence studies. Ophthalmic Epidemiology 2004;11 (2):67-115.
Perera 2007

Perera R, Glasziou P. A simple method to correct for the design effect in systematic reviews of trials using paired dichotomous data. Journal of Clinical Epidemiology 2007; 60(9): $975-8$.

Polack 2008

Polack S, Kuper H, Eusebio C, Mathenge W, Wadud $Z$, Foster A. The impact of cataract on time-use: results from a population based case-control study in Kenya, the Philippines and Bangladesh. Ophthalmic Epidemiology 2008;15(6):372-82.

Polack 2010

Polack S, Eusebio C, Mathenge W, Wadud Z, Rashid M, Foster A, et al. The impact of cataract surgery on activities and time-use: results from a longitudinal study in Kenya, Bangladesh and the Philippines. PloS One 2010;5(6): e10913.

\section{Resnikoff 2004}

Resnikoff S, Passolini D, Etyalale D, Kocur I, Pararajasegarm R, Pokharel GP, et al. Global data on visual impairment in the year 2002. Bulletin of The World Health Organization 2004;82(11):844-51.

\section{RevMan 2012 [Computer program]}

The Nordic Cochrane Centre, The Cochrane Collaboration. Review Manager (RevMan). Version 5.2. Copenhagen: The Nordic Cochrane Centre, The Cochrane Collaboration, 2012.

Riaz 2006

Riaz Y, Mehta JS, Wormald R, Evans JR, Foster A, Ravilla $\mathrm{T}$, et al. Surgical interventions for age-related cataract. Cochrane Database of Systematic Reviews 2006, Issue 4. [DOI: 10.1002/14651858.CD001323.pub2]

\section{Riaz 2013}

Riaz Y, de Silva SR, Evans JR. Manual small incision cataract surgery (MSICS) with posterior chamber intraocular lens versus phacoemulsification with posterior chamber intraocular lens for age-related cataract. Cochrane Database of Systematic Reviews 2013, Issue 10. [DOI: 10.1002/ 14651858.CD008813.pub2]

\section{References to other published versions of this review}

Riaz 2010

Riaz Y, Malik ANJ, Evans JR. Phacoemulsification with posterior chamber intraocular lens versus extracapsular cataract extraction (ECCE) with posterior chamber intraocular lens for age-related cataract. Cochrane Database of Systematic Reviews 2010, Issue 11. [DOI: 10.1002/ 14651858.CD008812]

* Indicates the major publication for the study 


\section{CHARACTERISTICS OF STUDIES}

\section{Characteristics of included studies [ordered by study ID]}

\section{Chee 1999}

\begin{tabular}{|c|c|}
\hline Methods & $\begin{array}{l}\text { Parallel-group randomised controlled trial } \\
\text { Number randomised: } 34 \text { participants } \\
\text { Unclear but likely that people were randomly allocated and } 1 \text { eye per person operated } \\
\text { Length of follow-up } 90 \text { days }\end{array}$ \\
\hline Participants & $\begin{array}{l}\text { Country: Singapore } \\
\text { Inclusion criteria: age-related cataract } \\
\text { Exclusion criteria: diabetics } \\
\text { Age, years: mean } 63.1 \\
\text { Gender: } 15 \text { men, } 19 \text { women } \\
\text { Ethnicity: Chinese and Malay }\end{array}$ \\
\hline Interventions & Phacoemulsification ( 18 eyes) versus ECCE ( 16 eyes) \\
\hline Outcomes & $\begin{array}{l}\text { Postoperative inflammation measured at post-operative day } 4,8,15,30,60,90 \text { with } \\
\text { laser flare meter/slit lamp } \\
\text { Snellen VA at } 2 \text { months }\end{array}$ \\
\hline Notes & Published data only. No correspondence with authors \\
\hline
\end{tabular}

\section{Risk of bias}

\begin{tabular}{|c|c|c|}
\hline Bias & Authors' judgement & Support for judgement \\
\hline $\begin{array}{l}\text { Random sequence generation (selection } \\
\text { bias) }\end{array}$ & Unclear risk & $\begin{array}{l}\text { "Patients having cataract surgery were ran- } \\
\text { domized to ECCE or phacoemulsification. } \\
\text { " Page } 1281 \\
\text { Details of randomisation procedure not } \\
\text { stated }\end{array}$ \\
\hline Allocation concealment (selection bias) & Unclear risk & Details not stated \\
\hline $\begin{array}{l}\text { Blinding of participants and personnel } \\
\text { (performance bias) } \\
\text { All outcomes }\end{array}$ & Unclear risk & $\begin{array}{l}\text { "Also, to reduce bias, two surgeons per- } \\
\text { formed both types of surgery" Page } 1281 \\
\text { Not stated if participant masked to type of } \\
\text { surgery }\end{array}$ \\
\hline $\begin{array}{l}\text { Blinding of outcome assessment (detection } \\
\text { bias) } \\
\text { All outcomes }\end{array}$ & Unclear risk & $\begin{array}{l}\text { " } 1 \text { independent postoperative observer (M. } \\
\text { S.) was masked as to surgical procedure" } \\
\text { Page } 1281 \text { (suture techniques different) }\end{array}$ \\
\hline $\begin{array}{l}\text { Incomplete outcome data (attrition bias) } \\
\text { All outcomes }\end{array}$ & Low risk & $\begin{array}{l}\text { There is no indication in the paper that } \\
\text { any participants did not complete the full } \\
\text { follow-up period }\end{array}$ \\
\hline
\end{tabular}

Phacoemulsification with posterior chamber intraocular lens versus extracapsular cataract extraction (ECCE) with posterior chamber 21 intraocular lens for age-related cataract (Review)

Copyright $\odot 2014$ The Cochrane Collaboration. Published by John Wiley \& Sons, Ltd. 
Chee 1999 (Continued)

\begin{tabular}{|c|c|c|}
\hline Selective reporting (reporting bias) & Low risk & None obvious \\
\hline
\end{tabular}

Díaz-Valle 1998

\begin{tabular}{ll} 
Methods & $\begin{array}{l}\text { Parallel-group randomised controlled trial } \\
\text { Total number of participants: } 60 \\
1 \text { eye per person included in the trial; unclear how the eye was selected for surgery } \\
\text { Length of follow-up: } 3 \text { months }\end{array}$ \\
\hline Participants & $\begin{array}{l}\text { Country: Spain } \\
\text { Inclusion criteria: age-related cataract } \\
\text { Exclusion criteria: other ocular pathologies, high refractive defects, glaucoma, diabetes } \\
\text { mellitus, and intraoperative or postoperative complications } \\
\text { Age, years: mean } 70.5 \text { years }+/-7.6 \text { (range } 58 \text { to } 79 \text { years) } \\
\text { Gender: } 27 \text { men, } 33 \text { women }\end{array}$ \\
\hline Interventions & $\begin{array}{l}\text { Group1: phacoemulsification (20 eyes) } \\
\text { Group 2: ECCE with planned continuous curvilinear capsulorhexis (20 eyes) } \\
\text { Group3: ECCE with letterbox capsulotomy (20 eyes) }\end{array}$ \\
\hline Outcomes & $\begin{array}{l}\text { Endothelial permeability } \\
\text { Endothelial cell loss } \\
\text { Pachymetry }\end{array}$ \\
\hline Notes & Published data only. No correspondence with authors \\
\hline
\end{tabular}

Risk of bias

\begin{tabular}{l|l|l}
\hline Bias & Authors' judgement & Support for judgement \\
\hline $\begin{array}{l}\text { Random sequence generation (selection } \\
\text { bias) }\end{array}$ & Unclear risk & No details stated in paper \\
\hline $\begin{array}{l}\text { Allocation concealment (selection bias) } \\
\text { Blinding of participants and personnel } \\
\text { (performance bias) } \\
\text { All outcomes }\end{array}$ & Unclear risk & No details stated in paper \\
\hline $\begin{array}{l}\text { Blinding of outcome assessment (detection } \\
\text { bias) } \\
\text { All outcomes }\end{array}$ & Unclear risk & $\begin{array}{l}\text { "All surgery was performed by the same sur- } \\
\text { geon." Page 952 } \\
\text { No details regarding masking of surgeon, } \\
\text { participants or other staff given }\end{array}$ \\
\hline $\begin{array}{l}\text { Incomplete outcome data (attrition bias) } \\
\text { All outcomes }\end{array}$ & Low risk & Not detailed in paper \\
\hline
\end{tabular}

Phacoemulsification with posterior chamber intraocular lens versus extracapsular cataract extraction (ECCE) with posterior chamber 


\section{Díaz-Valle 1998 (Continued)}

Selective reporting (reporting bias) Unclear risk

No details of intraoperative complications recorded in paper

George 2005

\begin{tabular}{|c|c|c|}
\hline Methods & \multicolumn{2}{|c|}{$\begin{array}{l}\text { Parallel-group randomised controlled trial } \\
\text { Number randomised: } 186 \text { participants } \\
\text { Unclear but likely that people were randomly allocated and } 1 \text { eye per person operated } \\
\text { Follow-up: } 3 \text { to } 4 \text { weeks (phaco), } 8 \text { weeks (ECCE) }\end{array}$} \\
\hline Participants & \multicolumn{2}{|c|}{$\begin{array}{l}\text { Country: India } \\
\text { Inclusion criteria: participant undergoing planned cataract surgery; otherwise normal } \\
\text { preoperative examination; cataract < grade III } \\
\text { Exclusion criteria: other potential causes of decreased vision; complicated cataracts; non } \\
\text { age-related cataracts; phacodonesis; glaucoma or retinal pathology } \\
\text { Age, years: phacoemulsification: } 59.63 \text { (SD 7.64) years, ECCE } 57.85 \text { (SD 8.01) years } \\
\text { Gender: phacoemulsification } 27 \text { men, } 33 \text { women, ECCE } 23 \text { men, } 29 \text { women }\end{array}$} \\
\hline Interventions & \multicolumn{2}{|c|}{ Phacoemulsification (62 eyes) versus ECCE ( 62 eyes) versus MSICS (62 eyes) } \\
\hline Outcomes & \multicolumn{2}{|c|}{$\begin{array}{l}\text { Surgically induced astigmatism } \\
\text { Endothelial cell loss } \\
\text { Snellen visual acuity }\end{array}$} \\
\hline Notes & \multicolumn{2}{|c|}{$\begin{array}{l}\text { Published data only. No correspondence with authors } \\
\text { Phacoemulsification - } 5 \mathrm{~mm} \text { incision rigid lens } \\
\text { ECCE - can-opener capsulotomy }\end{array}$} \\
\hline \multicolumn{3}{|l|}{ Risk of bias } \\
\hline Bias & Authors' judgement & Support for judgement \\
\hline $\begin{array}{l}\text { Random sequence generation (selection } \\
\text { bias) }\end{array}$ & Low risk & $\begin{array}{l}\text { "Cases were randomized into three groups } \\
\text { based on computer-generated random } \\
\text { numbers. Randomization was carried out } \\
\text { at the time of admission and used the hos- } \\
\text { pital numbers (which were allotted at the } \\
\text { time of the first hospital visit) for allocation } \\
\text { into different groups". Page } 294\end{array}$ \\
\hline Allocation concealment (selection bias) & Unclear risk & Not detailed in paper \\
\hline $\begin{array}{l}\text { Blinding of participants and personnel } \\
\text { (performance bias) } \\
\text { All outcomes }\end{array}$ & Unclear risk & $\begin{array}{l}\text { Study does not document whether partici- } \\
\text { pants or personnel were aware/informed of } \\
\text { which intervention they were assigned to }\end{array}$ \\
\hline
\end{tabular}

Phacoemulsification with posterior chamber intraocular lens versus extracapsular cataract extraction (ECCE) with posterior chamber 


\section{George 2005 (Continued)}

\begin{tabular}{l|l|l}
$\begin{array}{l}\text { Blinding of outcome assessment (detection } \\
\text { bias) } \\
\text { All outcomes }\end{array}$ & Unclear risk & $\begin{array}{l}\text { "Independent observers performed refrac- } \\
\text { tion and keratometry in order to minimize } \\
\text { bias". Page } 295\end{array}$ \\
\hline $\begin{array}{l}\text { Incomplete outcome data (attrition bias) } \\
\text { All outcomes }\end{array}$ & Unclear risk & $\begin{array}{l}\text { The } 6 \text {-week follow-up was completed by } \\
52 / 62 \text { cases of ECCE, 53/62 cases of } \\
\text { MSICS and } 60 / 62 \text { cases of phacoemulsif- } \\
\text { cation } \\
\text { The reasons for attrition were not stated }\end{array}$ \\
\hline Selective reporting (reporting bias) & Low risk & None obvious
\end{tabular}

\section{Kara-Junior 2010}

\begin{tabular}{|c|c|c|}
\hline Methods & \multicolumn{2}{|c|}{$\begin{array}{l}\text { Parallel-group randomised controlled trial } \\
\text { Number randomised: } 205 \text { participants } \\
\text { Each person only had } 1 \text { eye operated; it was not clear how the eye was selected } \\
\text { Follow-up: } 8 \text { weeks }\end{array}$} \\
\hline Participants & \multicolumn{2}{|c|}{$\begin{array}{l}\text { Country: Brazil } \\
\text { Inclusion criteria: age } 41 \text { to } 80 \text { years, senile cataract, BCVA worse than } 20 / 40 \text { or logMAR } \\
0.3 \text { in better eye, participant living less than } 100 \mathrm{~km} \text { from hospital } \\
\text { Exclusion criteria: presence of any physical or clinical restrictions besides visual problem, } \\
\text { presence of any ocular disease that could contribute to decreased visual acuity, previous } \\
\text { ocular surgery, amblyopia } \\
\text { Age, years: phacoemulsification: mean } 68.3 \text { (SD 9) years, ECCE } 69.1 \text { (SD } 8.5 \text { ) years } \\
\text { Gender: phacoemulsification: } 35.3 \% \text { men, ECCE } 44.1 \% \text { men }\end{array}$} \\
\hline Interventions & \multicolumn{2}{|c|}{ Phacoemulsification (101 eyes) versus ECCE (104 eyes) } \\
\hline Outcomes & \multicolumn{2}{|c|}{$\begin{array}{l}\text { Governmental cost of participants undergoing phacoemulsification and ECCE } \\
\text { Benefits after cataract surgery in productivity at work and motivation to seek work } \\
\text { Social costs (for employers, participants, care givers and social security) }\end{array}$} \\
\hline Notes & \multicolumn{2}{|c|}{ Published data only. No correspondence with authors } \\
\hline \multicolumn{3}{|l|}{ Risk of bias } \\
\hline Bias & Authors' judgement & Support for judgement \\
\hline $\begin{array}{l}\text { Random sequence generation (selection } \\
\text { bias) }\end{array}$ & Unclear risk & $\begin{array}{l}\text { "The selected patients were randomly as- } \\
\text { signed to two groups" Page } 2 \\
\text { Details of the method of randomisation are } \\
\text { not stated }\end{array}$ \\
\hline Allocation concealment (selection bias) & Unclear risk & Not detailed in paper \\
\hline
\end{tabular}


Kara-Junior 2010 (Continued)

\begin{tabular}{|c|c|c|}
\hline $\begin{array}{l}\text { Blinding of participants and personnel } \\
\text { (performance bias) } \\
\text { All outcomes }\end{array}$ & Unclear risk & Not detailed in paper \\
\hline $\begin{array}{l}\text { Blinding of outcome assessment (detection } \\
\text { bias) } \\
\text { All outcomes }\end{array}$ & Unclear risk & Not detailed in paper \\
\hline $\begin{array}{l}\text { Incomplete outcome data (attrition bias) } \\
\text { All outcomes }\end{array}$ & Unclear risk & $\begin{array}{l}\text { Only } 17 \text { participants in phacoemulsifica- } \\
\text { tion group and } 14 \text { participants in ECCE } \\
\text { group were employed, and the estimated } \\
\text { social security costs per participant were } \\
\text { based on these sample sizes only. (The re- } \\
\text { maining participants were retired, home- } \\
\text { makers, seeking employment or not look- } \\
\text { ing for a job) }\end{array}$ \\
\hline Selective reporting (reporting bias) & Unclear risk & $\begin{array}{l}\text { None related to defined outcomes (cost of } \\
\text { surgery) }\end{array}$ \\
\hline
\end{tabular}

Katsimpris 2004

\begin{tabular}{ll}
\hline Methods & $\begin{array}{l}\text { Randomised controlled trial } \\
\text { Number randomised: } 94 \text { participants } \\
\text { Each person only had } 1 \text { eye operated; it was not clear how the eye was selected } \\
\text { Follow-up: mean } 14 \pm 6.2 \text { months }\end{array}$ \\
\hline Participants & $\begin{array}{l}\text { Country: Greece } \\
\text { Inclusion criteria: particpants with cataract in association with pseudoexfoliation; small } \\
\text { pupil; small to moderate phacodonesis }\end{array}$ \\
$\begin{array}{ll}\text { Exclusion criteria: partial or complete subluxation; vitreous present in anterior chamber } \\
\text { Age, years: phacoemulsification: } 77 \text { (SD 5.3) years, ECCE 75.5 (SD 6.0) }\end{array}$ \\
\hline Interventions & \begin{tabular}{l} 
Phacoemulsification (47 eyes) versus ECCE (47 eyes) \\
\hline Outcomes
\end{tabular} \\
\hline $\begin{array}{l}\text { Intraoperative zonular tears } \\
\text { Capsular rupture } \\
\text { Vitreous loss } \\
\text { Corneal oedema } \\
\text { LogMAR visual acuity } \\
\text { Posterior capsule opacification } \\
\text { Intraocular pressure spikes } \\
\text { IOL decentration }\end{array}$ \\
\hline Potes & \begin{tabular}{l} 
Published data only. No correspondence with authors \\
\hline
\end{tabular} \\
\hline
\end{tabular}

\section{Risk of bias}

Phacoemulsification with posterior chamber intraocular lens versus extracapsular cataract extraction (ECCE) with posterior chamber 
Katsimpris 2004 (Continued)

\begin{tabular}{l|l|l}
\hline Bias & Authors' judgement & Support for judgement \\
\hline $\begin{array}{l}\text { Random sequence generation (selection } \\
\text { bias) }\end{array}$ & Unclear risk & Not detailed in paper \\
\hline $\begin{array}{l}\text { Allocation concealment (selection bias) } \\
\text { Blinding of participants and personnel } \\
\text { (performance bias) }\end{array}$ & Unclear risk & Not detailed in paper \\
\hline $\begin{array}{l}\text { All outcomes } \\
\text { Blinding of outcome assessment (detection } \\
\text { bias) } \\
\text { All outcomes }\end{array}$ & Unclear risk & Not detailed in paper \\
\hline $\begin{array}{l}\text { Incomplete outcome data (attrition bias) } \\
\text { All outcomes }\end{array}$ & Low risk & Not detailed in paper \\
\hline \begin{tabular}{l} 
Selective reporting (reporting bias) \\
\hline
\end{tabular} & Low risk & $\begin{array}{l}\text { No details of any participant not complet- } \\
\text { ing follow-up }\end{array}$ \\
\hline
\end{tabular}

\section{Landau 1999}

Methods

Parallel-group randomised controlled trial

Number randomised: 42 participants (21 to phacoemulsification, 21 to ECCE)

Each person only had 1 eye operated; it was not clear how the eye was selected

Follow-up: 1.5 to 2.5 years

Country: Sweden
Inclusion criteria: participants with cataract
Exclusion criteria: no other ocular disease
Age, years: mean (range) 74.25 (68 to 82 ) years
Gender: 11 men, 24 women (35 participants followed up)

$\begin{array}{ll}\text { Interventions } & 35 \text { participants followed up } \\ & \text { Phacoemulsification (17 eyes) versus ECCE (18 eyes) }\end{array}$

Outcomes Ultrasound biomicroscopy examination of IOL haptic position

Anterior chamber depth

Notes

Published data only. No correspondence with authors

\section{Risk of bias}

\begin{tabular}{|c|c|c|}
\hline Bias & Authors' judgement & Support for judgement \\
\hline $\begin{array}{l}\text { Random sequence generation (selection } \\
\text { bias) }\end{array}$ & Low risk & $\begin{array}{l}\text { "At the preoperative examination the pa- } \\
\text { tients were randomly assigned to Group I }\end{array}$ \\
\hline
\end{tabular}

Phacoemulsification with posterior chamber intraocular lens versus extracapsular cataract extraction (ECCE) with posterior chamber 
Landau 1999 (Continued)

or Group II by a computer generated randomisation schedule". Page 394

\begin{tabular}{|c|c|c|}
\hline Allocation concealment (selection bias) & Unclear risk & Not stated in paper \\
\hline $\begin{array}{l}\text { Blinding of participants and personnel } \\
\text { (performance bias) } \\
\text { All outcomes }\end{array}$ & Low risk & $\begin{array}{l}\text { "The patients were unaware of the surgical } \\
\text { technique used". Page } 394\end{array}$ \\
\hline $\begin{array}{l}\text { Blinding of outcome assessment (detection } \\
\text { bias) } \\
\text { All outcomes }\end{array}$ & Low risk & $\begin{array}{l}\text { "All UBM examinations were performed } \\
\text { by one of the authors who was unaware } \\
\text { of the surgical technique used for cataract } \\
\text { extraction". Page } 395\end{array}$ \\
\hline $\begin{array}{l}\text { Incomplete outcome data (attrition bias) } \\
\text { All outcomes }\end{array}$ & Low risk & $\begin{array}{l}\text { "Two patients died before the start of the } \\
\text { UBM study and five declined to be exam- } \\
\text { ined by UBM". Page } 395\end{array}$ \\
\hline Selective reporting (reporting bias) & Low risk & None obvious \\
\hline
\end{tabular}

\section{Laurell 1998}

\begin{tabular}{|c|c|}
\hline Methods & $\begin{array}{l}\text { Randomised controlled trial } \\
\text { Number randomised: } 42 \text { participants } \\
\text { Follow-up: } 2 \text { years }\end{array}$ \\
\hline Participants & $\begin{array}{l}\text { Country: Sweden } \\
\text { Inclusion criteria: participants enrolled for cataract surgery; age } 64 \text { to } 82 \text { years } \\
\text { Exclusion criteria: pseudoexfoliation syndrome; small pupils ( }<5 \mathrm{~mm} \text { post dilatation); } \\
\text { glaucoma; uveitis; dark brown irides; diabetes; treatment with eye drops or anti-inflam- } \\
\text { matory drugs } \\
\text { Age, years: phacoemulsification: median } 73 \text { years, range } 65 \text { to } 82 \text {, ECCE: range } 64 \text { to } \\
79 \\
\text { Gender: phacoemulsification } 62 \% \text { women, ECCE } 67 \% \text { women }\end{array}$ \\
\hline Interventions & Phacoemulsification ( 21 eyes) versus ECCE (21 eyes) \\
\hline Outcomes & $\begin{array}{l}\text { Operation time } \\
\text { Blood-aqueous barrier reaction ( } 3 \text { months) } \\
\text { Laser flare meter in anterior chamber ( } 2 \text { years) } \\
\text { Snellen visual acuity ( } 3 \text { months) } \\
\text { Corneal thickness (at } 3 \text { months) }\end{array}$ \\
\hline Notes & $\begin{array}{l}\text { Envelope capsulotomy for ECCE } \\
\text { Published data only. No correspondence with authors }\end{array}$ \\
\hline
\end{tabular}

\section{Risk of bias}




\section{Laurell 1998 (Continued)}

\begin{tabular}{|c|c|c|}
\hline Bias & Authors' judgement & Support for judgement \\
\hline $\begin{array}{l}\text { Random sequence generation (selection } \\
\text { bias) }\end{array}$ & Low risk & $\begin{array}{l}\text { "randomly assigned to phacoemulsification } \\
\text { (group I) or ECCE (group II) by a com- } \\
\text { puter generated randomisation schedule } \\
\text { thus the allocation was not dependent on } \\
\text { characteristics of the eye" Page } 574\end{array}$ \\
\hline Allocation concealment (selection bias) & Low risk & $\begin{array}{l}\text { "The patients were not informed about the } \\
\text { surgical method". Page } 574\end{array}$ \\
\hline $\begin{array}{l}\text { Blinding of participants and personnel } \\
\text { (performance bias) } \\
\text { All outcomes }\end{array}$ & Unclear risk & Not stated in paper \\
\hline $\begin{array}{l}\text { Blinding of outcome assessment (detection } \\
\text { bias) } \\
\text { All outcomes }\end{array}$ & Low risk & $\begin{array}{l}\text { "the analyst was not aware of the surgical } \\
\text { method at the time of calculation of diffu- } \\
\text { sion coefficients". Page } 575\end{array}$ \\
\hline $\begin{array}{l}\text { Incomplete outcome data (attrition bias) } \\
\text { All outcomes }\end{array}$ & High risk & $\begin{array}{l}\text { Not all visual acuity data reported for all } \\
\text { participants } \\
\text { "One patient in group II died between } \\
\text { the three months and one year examina- } \\
\text { tions. In group I the BAB measurements of } \\
\text { one participant were discarded because fine } \\
\text { pseudoexfoliations were found after the pa- } \\
\text { tient had entered the study. the other drop- } \\
\text { outs were due to patients unavailable for } \\
\text { follow up". Page } 575\end{array}$ \\
\hline Selective reporting (reporting bias) & Unclear risk & $\begin{array}{l}\text { No details of intraoperative complications } \\
\text { recorded in paper }\end{array}$ \\
\hline
\end{tabular}

\section{MEHOX 2004}

Methods

Randomised controlled trial ( 2 centres)

Number randomised: 500 participants (251 participants randomised to phacoemulsification, 249 to ECCE)

Each person only had 1 eye operated, "The choice of eye in those with bilateral cataracts was as in routine clinical practice, and was independent of the allocated surgical treatmentthat is, was made before randomisation."

Length of follow-up: 1 year

Participants

Country: UK

Inclusion criteria: consenting participant; age-related cataract; resident in the region; willing and able to attend regular follow-up

Exclusion criteria: hard, highly brunescent cataracts; eye disorders that may compromise vision (e.g. amblyopia, glaucoma, diabetic retinopathy, macular degeneration); high my- 
MEHOX 2004

\begin{tabular}{ll} 
& $\begin{array}{l}\text { opes (axial length }>26.5 \mathrm{~mm}) \\
\text { Age, years: mean 72, range 40+ years } \\
\text { Gender: (of people with complete data): phacoemulsification } 91 \text { men, } 132 \text { women, } \\
\text { ECCE } 97 \text { men, } 113 \text { women }\end{array}$ \\
\hline Interventions & $\begin{array}{l}\text { Phacoemulsification (244 participants received the allocated treatment) versus ECCE } \\
(232 \text { participants) }\end{array}$ \\
\hline Outcomes & $\begin{array}{l}439 \text { participants completed trial, } 433 \text { participants had complete data } \\
\text { Snellen visual acuity } \\
\text { Astigmatism } \\
\text { Capsule rupture/vitreous loss } \\
\text { Capsule opacity at } 1 \text { year } \\
\text { Endothelial cell loss }\end{array}$ \\
\hline Notes & \begin{tabular}{l} 
Published data only. No correspondence with authors \\
\hline
\end{tabular} \\
\hline
\end{tabular}

Risk of bias

\begin{tabular}{|c|c|c|}
\hline Bias & Authors' judgement & Support for judgement \\
\hline $\begin{array}{l}\text { Random sequence generation (selection } \\
\text { bias) }\end{array}$ & Low risk & $\begin{array}{l}\text { "The unit of randomisation was the indi- } \\
\text { vidual patient, with only one eye consid- } \\
\text { ered for cataract surgery. The randomisa- } \\
\text { tion was stratified by surgeon with blocks } \\
\text { of size four and six". Page } 825\end{array}$ \\
\hline Allocation concealment (selection bias) & Low risk & $\begin{array}{l}\text { "The allocation codes were sealed in se- } \\
\text { quentially numbered opaque envelopes, } \\
\text { and placed in the care of the trial man- } \\
\text { ager in each study centre. The participating } \\
\text { surgeons were not involved in the care of } \\
\text { or opening of the envelopes, and were in- } \\
\text { formed of the treatment assignment in the- } \\
\text { atre immediately before surgery. The trial } \\
\text { statistician who generated the allocation } \\
\text { schedules was not involved in execution of } \\
\text { the assignment". Page } 825\end{array}$ \\
\hline
\end{tabular}

Blinding of participants and personnel Low risk (performance bias)

All outcomes

Blinding of outcome assessment (detection Low risk bias)

All outcomes
"As in many surgical trials, complete masking was not possible. The patients and the optometrists in charge of the follow up outcome assessments were masked to the treatment allocation code“. Page 825

"optometrists in charge of the follow up outcome assessments were masked to the treatment allocation code. The optometrists examining the patient, however, 
Incomplete outcome data (attrition bias) Unclear risk All outcomes could not be masked to the size and location of the surgical incision, which indicated the type of surgery". Page 825

"similar numbers were lost in the two treatment groups, and the reasons for lossmainly problems with attendance due to change of residence or death-were similar in the two groups". Page 828

\begin{tabular}{|c|c|}
\hline Selective reporting (reporting bias) & Low risk \\
\hline
\end{tabular}

Ravalico 1997

\begin{tabular}{|c|c|}
\hline Methods & $\begin{array}{l}\text { Parallel-group randomised controlled trial } \\
\text { Number randomised: } 40 \text { participants } \\
\text { People were randomly allocated to treatment and likely (but not clearly stated) that } 1 \\
\text { eye per person operated } \\
\text { Follow-up: mean } 30 \text { days }\end{array}$ \\
\hline Participants & $\begin{array}{l}\text { Country: Italy } \\
\text { Inclusion criteria: participants scheduled for cataract surgery } \\
\text { Exclusion criteria: high refractive defects ( }>4.0 \text { dioptres); other ocular pathologies; dia- } \\
\text { betes mellitus; intraoperative or postoperative complications } \\
\text { Age, years: phacoemulsification mean } 62.9 \text { (SD 6.2) (range } 60 \text { to } 70 \text { ), ECCE: mean } 63 \text {. } \\
7 \text { (SD 6.7) years }\end{array}$ \\
\hline Interventions & Phacoemulsification (20 eyes) versus ECCE (20 eyes) \\
\hline Outcomes & $\begin{array}{l}\text { Mean endothelial cell density } \\
\text { Coefficient of variation in cell size } \\
\text { Pachymetry } \\
\text { Endothelial cell pump function and permeability coefficient } \\
\text { Mean decimal visual acuity }\end{array}$ \\
\hline Notes & Published data only. No correspondence with authors \\
\hline
\end{tabular}

\section{Risk of bias}

\begin{tabular}{|c|c|c|}
\hline Bias & Authors' judgement & Support for judgement \\
\hline $\begin{array}{l}\text { Random sequence generation (selection } \\
\text { bias) }\end{array}$ & Low risk & $\begin{array}{l}\text { "Forty patients scheduled for cataract } \\
\text { surgery were divided by randomization } \\
\text { numbers into two groups of } 20 \text { patients } \\
\text { each". Page } 1001\end{array}$ \\
\hline
\end{tabular}

Allocation concealment (selection bias) $\quad$ Unclear risk $\quad$ No details stated in paper 
Ravalico 1997 (Continued)

\begin{tabular}{|c|c|c|}
\hline $\begin{array}{l}\text { Blinding of participants and personnel } \\
\text { (performance bias) } \\
\text { All outcomes }\end{array}$ & Unclear risk & $\begin{array}{l}\text { "All ECCE and phacoemulsification proce- } \\
\text { dures were performed by the same surgeon. } \\
\text { " Page } 1001 \\
\text { No details regarding masking of partici- } \\
\text { pants or other staff given }\end{array}$ \\
\hline $\begin{array}{l}\text { Blinding of outcome assessment (detection } \\
\text { bias) } \\
\text { All outcomes }\end{array}$ & Unclear risk & No details stated in paper \\
\hline $\begin{array}{l}\text { Incomplete outcome data (attrition bias) } \\
\text { All outcomes }\end{array}$ & Low risk & $\begin{array}{l}\text { "No patient dropped out of the study". } \\
\text { Page } 1001\end{array}$ \\
\hline Selective reporting (reporting bias) & Unclear risk & $\begin{array}{l}\text { No details of intraoperative complications } \\
\text { recorded in paper }\end{array}$ \\
\hline
\end{tabular}

Rizal 2003

Methods

Parallel-group randomised controlled trial

Number randomised: 60 participants

Unclear but likely that people were randomly allocated and 1 eye per person operated

Follow-up: 2 months

\begin{tabular}{ll} 
Participants & $\begin{array}{l}\text { Country: Malaysia } \\
\text { Inclusion criteria: age over 40, BCVA of } 6 / 60 \text { or better with symptoms of cataract } \\
\text { Exclusion criteria: senile dementia, frailty or deformity, have a past history of eye injury, } \\
\text { undergoing any major surgery within the study period, anxious participants who require } \\
\text { general anaesthesia, participants with cerebral vascular accident causing significant visual } \\
\text { loss. Participants with glaucoma, maculopathy, difficult pupillary dilation, media opacity } \\
\text { such as vitreous haemorrhage and any central corneal opacity of } 3 \text { mm diameter } \\
\text { Age, years: range } 45 \text { to } 94 \text { years } \\
\text { Gender: phacoemulsification } 12 \text { men, } 18 \text { women, ECCE } 12 \text { men, } 18 \text { women } \\
\text { Ethnicity: Malay, Chinese, Indian }\end{array}$ \\
\hline Interventions & Phacoemulsification (30 eyes) versus ECCE (30 eyes) \\
\hline Outcomes & Cataract surgery cost \\
\hline Notes & Published data only. No correspondence with authors
\end{tabular}

Risk of bias

\begin{tabular}{|c|c|c|}
\hline Bias & Authors' judgement & Support for judgement \\
\hline
\end{tabular}

Random sequence generation (selection Low risk bias)

"Using a computer generated randomisation table, they were subjected to either ECCE or PEA". Page 381

Phacoemulsification with posterior chamber intraocular lens versus extracapsular cataract extraction (ECCE) with posterior chamber 
Rizal 2003 (Continued)

\begin{tabular}{l|l|l}
\hline Allocation concealment (selection bias) & Unclear risk & Not detailed in paper \\
\hline $\begin{array}{l}\text { Blinding of participants and personnel } \\
\text { (performance bias) } \\
\text { All outcomes }\end{array}$ & Unclear risk & Not detailed in paper \\
\hline $\begin{array}{l}\text { Blinding of outcome assessment (detection } \\
\text { bias) } \\
\text { All outcomes }\end{array}$ & Unclear risk & Not detailed in paper \\
\hline $\begin{array}{l}\text { Incomplete outcome data (attrition bias) } \\
\text { All outcomes }\end{array}$ & Unclear risk & Not detailed in paper \\
\hline Selective reporting (reporting bias) & Unclear risk & $\begin{array}{l}\text { No details of intraoperative complications } \\
\text { recorded in paper }\end{array}$ \\
\hline
\end{tabular}

\section{Stumpf 2006}

\begin{tabular}{|c|c|c|}
\hline Methods & \multicolumn{2}{|c|}{$\begin{array}{l}\text { Randomised controlled trial } \\
\text { Number randomised: } 41 \text { eyes in } 39 \text { participants } \\
\text { Follow-up: } 180 \text { days }\end{array}$} \\
\hline Participants & \multicolumn{2}{|c|}{$\begin{array}{l}\text { Country: Brazil } \\
\text { Inclusion criteria: senile cataract with hard cataract, possibility of return examinations } \\
\text { for at least } 6 \text { months } \\
\text { Exclusion criteria: presence of ocular pathology, prior eye surgery in the eye studied, } \\
\text { diabetes mellitus, participants who were unable to do } 6 \text { months postoperative follow-up } \\
\text { Age, years: } 54 \text { to } 88 \\
\text { Gender: } 12 \text { men, } 27 \text { women }\end{array}$} \\
\hline Interventions & \multicolumn{2}{|c|}{ Phacoemulsification (20 eyes) versus ECCE (21 eyes) } \\
\hline Outcomes & \multicolumn{2}{|c|}{$\begin{array}{l}\text { Decimal VA at } 1,3 \text { and } 6 \text { months } \\
\text { Endothelial cell loss } \\
\text { Pachymetry }\end{array}$} \\
\hline Notes & \multicolumn{2}{|c|}{$\begin{array}{l}\text { Published data only (paper translated from Portuguese original). No correspondence } \\
\text { with authors }\end{array}$} \\
\hline \multicolumn{3}{|l|}{ Risk of bias } \\
\hline Bias & Authors' judgement & Support for judgement \\
\hline $\begin{array}{l}\text { Random sequence generation (selection } \\
\text { bias) }\end{array}$ & Low risk & $\begin{array}{l}\text { Participants were randomised using a bal- } \\
\text { lot system. "The patients were randomly } \\
\text { divided by lot into two groups". Page } 492\end{array}$ \\
\hline
\end{tabular}




\section{Stumpf 2006 (Continued)}

\begin{tabular}{l|l|l}
\hline Allocation concealment (selection bias) & Unclear risk & Not detailed in paper \\
\hline $\begin{array}{l}\text { Blinding of participants and personnel } \\
\text { (performance bias) } \\
\text { All outcomes }\end{array}$ & Unclear risk & Not detailed in paper \\
\hline $\begin{array}{l}\text { Blinding of outcome assessment (detection } \\
\text { bias) } \\
\text { All outcomes }\end{array}$ & Unclear risk & Not detailed in paper \\
\hline $\begin{array}{l}\text { Incomplete outcome data (attrition bias) } \\
\text { All outcomes }\end{array}$ & Low risk & $\begin{array}{l}\text { All participants completed 6-month fol- } \\
\text { low-up period }\end{array}$ \\
\hline \begin{tabular}{l} 
Selective reporting (reporting bias) \\
\hline
\end{tabular} & Unclear risk & $\begin{array}{l}\text { No details of intraoperative complications } \\
\text { recorded in paper }\end{array}$ \\
\hline
\end{tabular}

BCVA: best corrected visual acuity

ECCE: extracapsular cataract extraction

IOL: intraocular lens

MSICS: manual small incision cataract surgery

SD: standard deviation

UBM: ultrasound biomicroscopy

VA: visual acuity

\section{Characteristics of excluded studies [ordered by study ID]}

\begin{tabular}{l|l}
\hline Study & Reason for exclusion \\
\hline Arriaga 2002 & Not a RCT \\
\hline Balent 2001 & Not strictly a RCT. "Patients were randomly assigned to any surgeon's table as soon as the table emptied" \\
\hline Bellucci 1995 & Study in people with small pupils \\
\hline Bovet 1992 & Not a RCT \\
\hline Bovet 1994 & Not a RCT \\
\hline Bömer 1995 & Surgical technique was not randomly allocated \\
\hline Cavallini 1996 & Not a RCT \\
\hline Dam-Johansen 1993 & Not a RCT
\end{tabular}

Phacoemulsification with posterior chamber intraocular lens versus extracapsular cataract extraction (ECCE) with posterior chamber 
(Continued)

\begin{tabular}{|c|c|}
\hline Dowler 2000 & Participants were diabetic therefore may not have had age-related cataract \\
\hline Egger 1994 & Not a RCT \\
\hline Geerling 2000 & Not a RCT \\
\hline Grinbaum 2003 & Not a RCT \\
\hline Honda 1995 & Not a RCT \\
\hline Kim 1996 & Study of intraocular pressure change only \\
\hline Lagreze 1996 & Participants only randomly allocated to phacoemulsification, not to ECCE \\
\hline Li 2005 & Not a RCT \\
\hline Liu 1995 & Not a RCT \\
\hline Liu 2003a & Not a RCT \\
\hline Liu 2003b & Not a RCT \\
\hline Loo 2004 & Not a RCT \\
\hline Lupidi 1994 & Not a RCT \\
\hline Ma 2000 & Not a RCT \\
\hline Matheu 1997 & Does not compare phacoemulsification and ECCE \\
\hline Moulick 2009 & Not a RCT \\
\hline Muralikrishnan 2004 & Not a RCT \\
\hline Müller-Jensen 1996 & Not a RCT \\
\hline Okinami 1994 & Not a RCT \\
\hline Ram 2001 & Not a RCT \\
\hline Sun 2010 & Not a RCT \\
\hline Watson 1992 & Not a RCT \\
\hline Yasuyoshi 1995 & Not a RCT \\
\hline
\end{tabular}

ECCE: extracapsular cataract extraction

RCT: randomised controlled trial

Phacoemulsification with posterior chamber intraocular lens versus extracapsular cataract extraction (ECCE) with posterior chamber 
Characteristics of studies awaiting assessment [ordered by study ID]

Durovic 2004

Methods

Participants

Interventions

Outcomes

Notes Awaiting translation

Trnavec 1997

Methods

Participants

Interventions

Outcomes

Notes Awaiting translation

Phacoemulsification with posterior chamber intraocular lens versus extracapsular cataract extraction (ECCE) with posterior chamber 
DATA ANDANALYSES

Comparison 1. Phacoemulsification versus ECCE

\begin{tabular}{|c|c|c|c|c|}
\hline Outcome or subgroup title & $\begin{array}{l}\text { No. of } \\
\text { studies }\end{array}$ & $\begin{array}{c}\text { No. of } \\
\text { participants }\end{array}$ & Statistical method & Effect size \\
\hline $\begin{array}{l}1 \text { Good functional vision at } 3 \\
\text { months (uncorrected acuity) }\end{array}$ & 2 & 492 & Risk Ratio (M-H, Fixed, 95\% CI) & $1.81[1.36,2.41]$ \\
\hline $\begin{array}{l}2 \text { Good functional vision at } 12 \\
\text { months (uncorrected acuity) }\end{array}$ & 1 & & Risk Ratio (M-H, Fixed, 95\% CI) & Totals not selected \\
\hline $\begin{array}{l}3 \text { Good functional vision at } 3 \\
\text { months (best corrected acuity) }\end{array}$ & 4 & 645 & Risk Ratio (M-H, Random, 95\% CI) & $1.12[1.03,1.22]$ \\
\hline $\begin{array}{l}4 \text { Good functional vision at } 12 \\
\text { months (best corrected acuity) }\end{array}$ & 1 & & Risk Ratio (M-H, Fixed, 95\% CI) & Totals not selected \\
\hline $\begin{array}{l}5 \text { Poor visual outcome at } 3 \text { months } \\
\text { (best corrected acuity } 6 / 60 \text { or } \\
\text { worse) }\end{array}$ & 3 & 604 & Risk Ratio (M-H, Fixed, 95\% CI) & $0.33[0.20,0.55]$ \\
\hline $\begin{array}{l}6 \text { Poor visual outcome at } 12 \\
\text { months (best corrected acuity } \\
6 / 60 \text { or worse) }\end{array}$ & 1 & & Risk Ratio (M-H, Fixed, 95\% CI) & Totals not selected \\
\hline 7 Capsular rupture & 3 & 688 & Peto Odds Ratio (Peto, Fixed, 95\% CI) & $0.56[0.26,1.22]$ \\
\hline $8 \%$ corneal endothelial cell loss & 3 & 605 & Mean Difference (IV, Fixed, 95\% CI) & $1.00[-0.88,2.89]$ \\
\hline $\begin{array}{l}9 \text { Other intraoperative } \\
\text { complications }\end{array}$ & & & Other data & No numeric data \\
\hline 10 Posterior capsule opacification & 2 & 571 & Peto Odds Ratio (Peto, Fixed, 95\% CI) & $0.38[0.22,0.66]$ \\
\hline 11 Retinal detachment & 1 & & Peto Odds Ratio (Peto, Fixed, 95\% CI) & Totals not selected \\
\hline 12 Cystoid macular oedema & 2 & 571 & Peto Odds Ratio (Peto, Fixed, 95\% CI) & $0.29[0.10,0.86]$ \\
\hline 13 Iris prolapse & 1 & & Peto Odds Ratio (Peto, Fixed, 95\% CI) & Totals not selected \\
\hline 14 Other complications & & & Other data & No numeric data \\
\hline
\end{tabular}

Phacoemulsification with posterior chamber intraocular lens versus extracapsular cataract extraction (ECCE) with posterior chamber 


\section{Analysis I.I. Comparison I Phacoemulsification versus ECCE, Outcome I Good functional vision at 3 months (uncorrected acuity).}

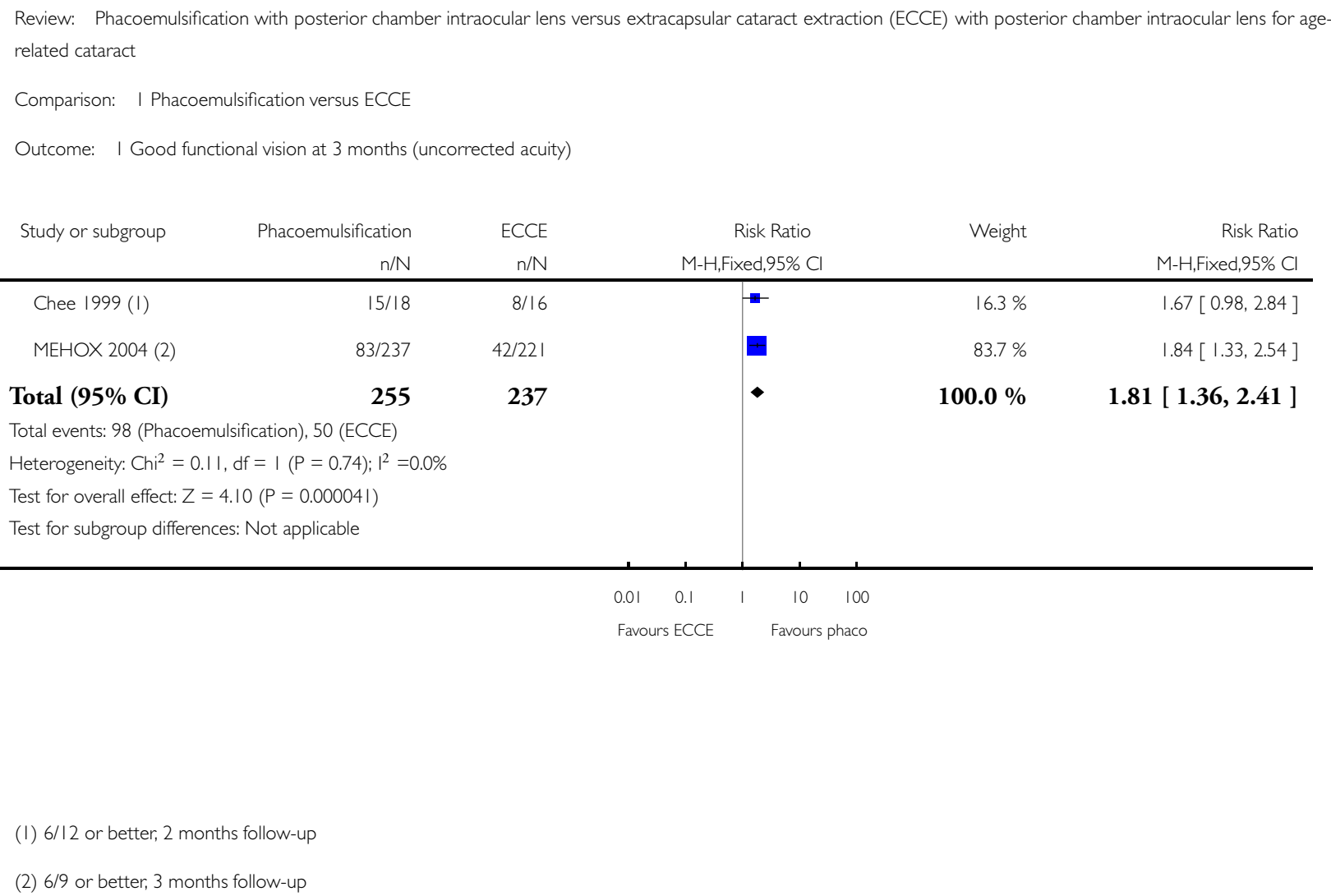

\section{Analysis I.2. Comparison I Phacoemulsification versus ECCE, Outcome 2 Good functional vision at I 2 months (uncorrected acuity).}

Review: Phacoemulsification with posterior chamber intraocular lens versus extracapsular cataract extraction (ECCE) with posterior chamber intraocular lens for agerelated cataract

Comparison: I Phacoemulsification versus ECCE

Outcome: 2 Good functional vision at 12 months (uncorrected acuity)

\begin{tabular}{|c|c|c|c|c|c|c|c|}
\hline \multirow[t]{2}{*}{ Study or subgroup } & \multirow{2}{*}{$\begin{array}{r}\text { Phacoemulsification } \\
n / N\end{array}$} & ECCE & \multicolumn{4}{|c|}{ Risk Ratio } & Risk Ratio \\
\hline & & $\mathrm{n} / \mathrm{N}$ & \multicolumn{4}{|c|}{ M-H,Fixed,95\% Cl } & M-H,Fixed,95\% Cl \\
\hline \multirow[t]{3}{*}{ MEHOX 2004 (I) } & $87 / 224$ & $42 / 215$ & & & + & & $1.99[1.45,2.73]$ \\
\hline & & & 0.01 & 0.1 & 10 & 100 & \\
\hline & & & \multicolumn{2}{|c|}{ Favours ECC } & Favours & haco & \\
\hline
\end{tabular}

Phacoemulsification with posterior chamber intraocular lens versus extracapsular cataract extraction (ECCE) with posterior chamber 
(1) 6/9 or better

\section{Analysis I.3. Comparison I Phacoemulsification versus ECCE, Outcome 3 Good functional vision at 3} months (best corrected acuity).

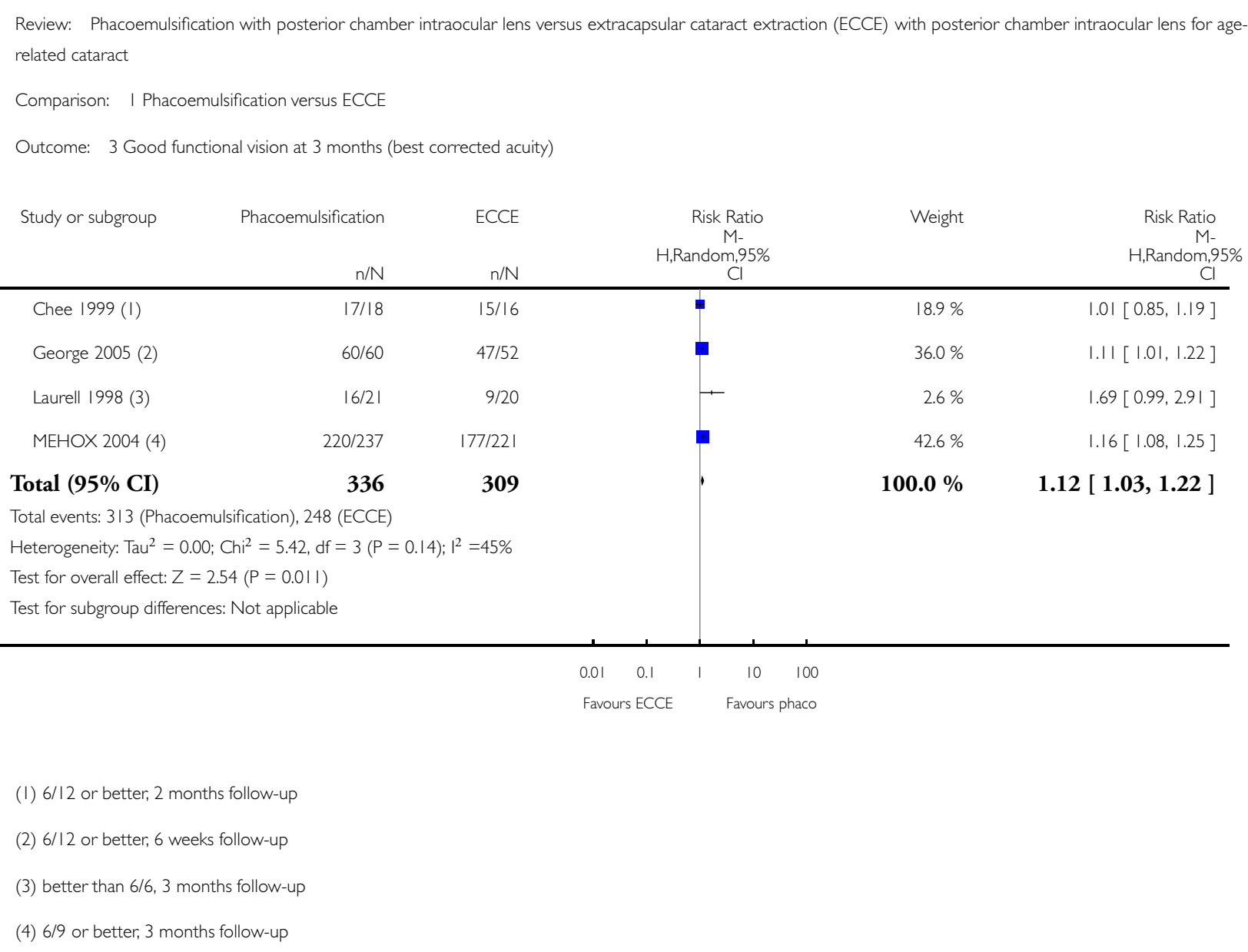

Phacoemulsification with posterior chamber intraocular lens versus extracapsular cataract extraction (ECCE) with posterior chamber 


\section{Analysis I.4. Comparison I Phacoemulsification versus ECCE, Outcome 4 Good functional vision at I2 months (best corrected acuity).}

Review: Phacoemulsification with posterior chamber intraocular lens versus extracapsular cataract extraction (ECCE) with posterior chamber intraocular lens for agerelated cataract

Comparison: I Phacoemulsification versus ECCE

Outcome: 4 Good functional vision at 12 months (best corrected acuity)

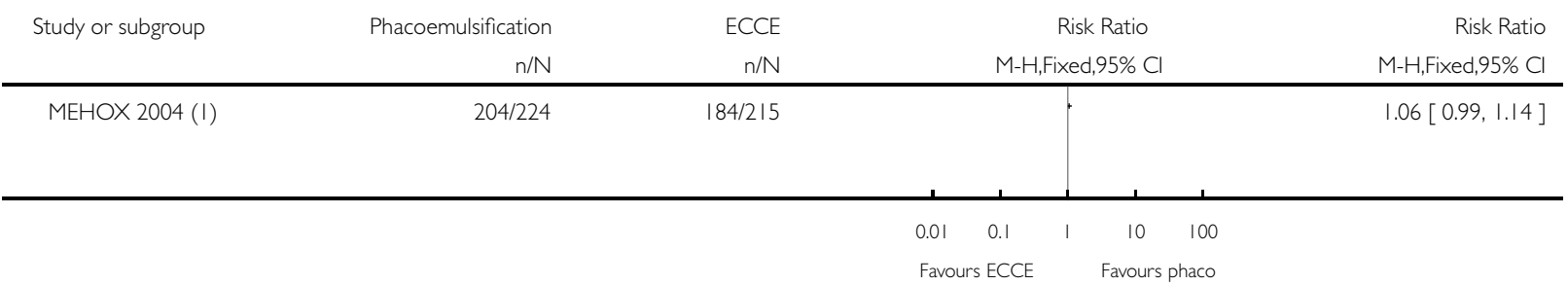

(1) $6 / 9$ or better

\section{Analysis I.5. Comparison I Phacoemulsification versus ECCE, Outcome 5 Poor visual outcome at 3 months (best corrected acuity $6 / 60$ or worse).}

Review: Phacoemulsification with posterior chamber intraocular lens versus extracapsular cataract extraction (ECCE) with posterior chamber intraocular lens for agerelated cataract

Comparison: I Phacoemulsification versus ECCE

Outcome: 5 Poor visual outcome at 3 months (best corrected acuity 6/60 or worse)

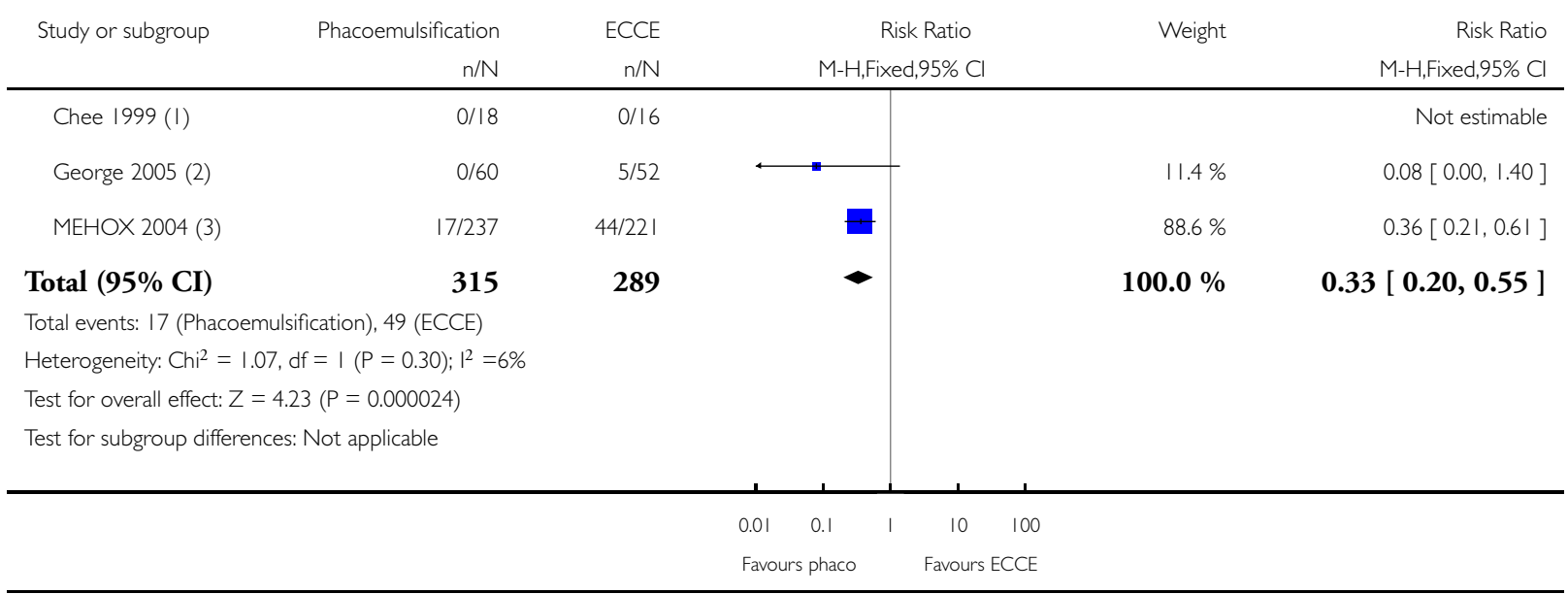

Phacoemulsification with posterior chamber intraocular lens versus extracapsular cataract extraction (ECCE) with posterior chamber 
(1) worse than 6/12, 2 months follow-up

(2) 6/18 or worse, 6 weeks follow-up

(3) worse than 6/9, 3 months follow-up

\section{Analysis I.6. Comparison I Phacoemulsification versus ECCE, Outcome 6 Poor visual outcome at I2} months (best corrected acuity $6 / 60$ or worse).

Review: Phacoemulsification with posterior chamber intraocular lens versus extracapsular cataract extraction (ECCE) with posterior chamber intraocular lens for agerelated cataract

Comparison: I Phacoemulsification versus ECCE

Outcome: 6 Poor visual outcome at 12 months (best corrected acuity 6/60 or worse)

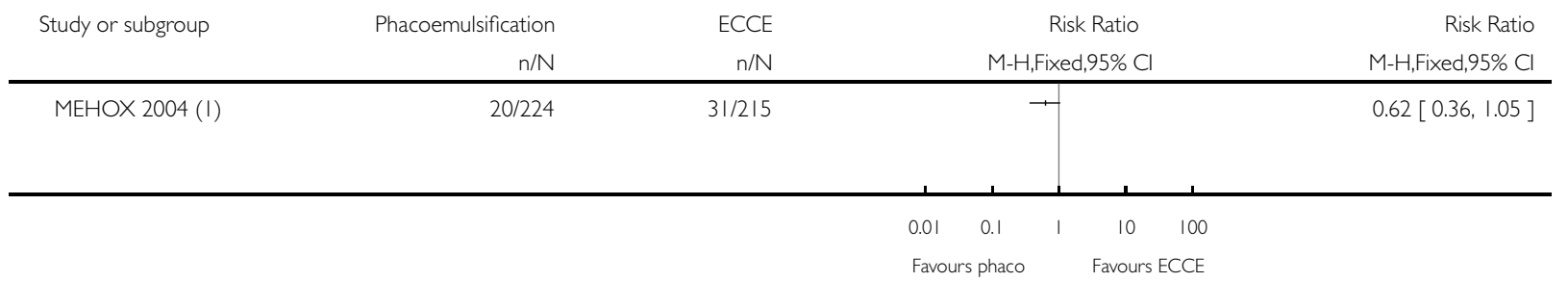

(1) worse than $6 / 9$

Phacoemulsification with posterior chamber intraocular lens versus extracapsular cataract extraction (ECCE) with posterior chamber 


\section{Analysis I.7. Comparison I Phacoemulsification versus ECCE, Outcome 7 Capsular rupture.}

Review: Phacoemulsification with posterior chamber intraocular lens versus extracapsular cataract extraction (ECCE) with posterior chamber intraocular lens for agerelated cataract

Comparison: I Phacoemulsification versus ECCE

Outcome: 7 Capsular rupture

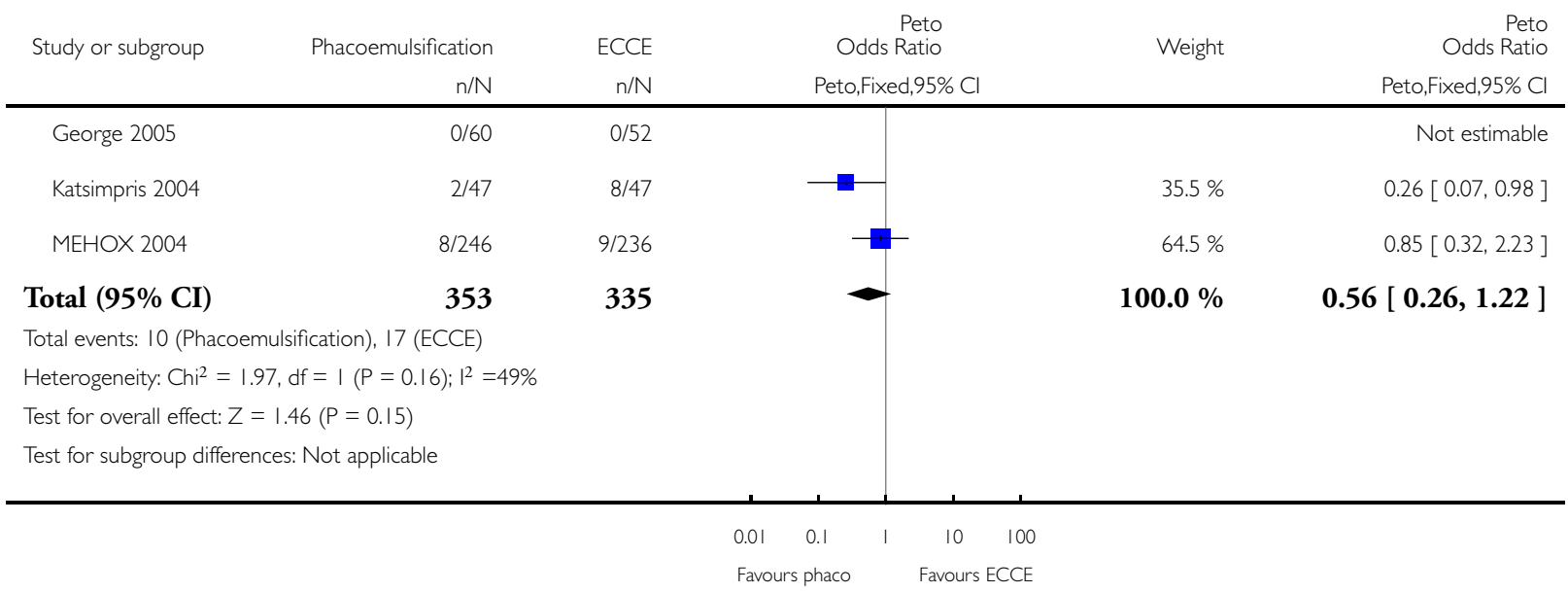

Phacoemulsification with posterior chamber intraocular lens versus extracapsular cataract extraction (ECCE) with posterior chamber 


\section{Analysis I.8. Comparison I Phacoemulsification versus ECCE, Outcome $8 \%$ corneal endothelial cell loss.}

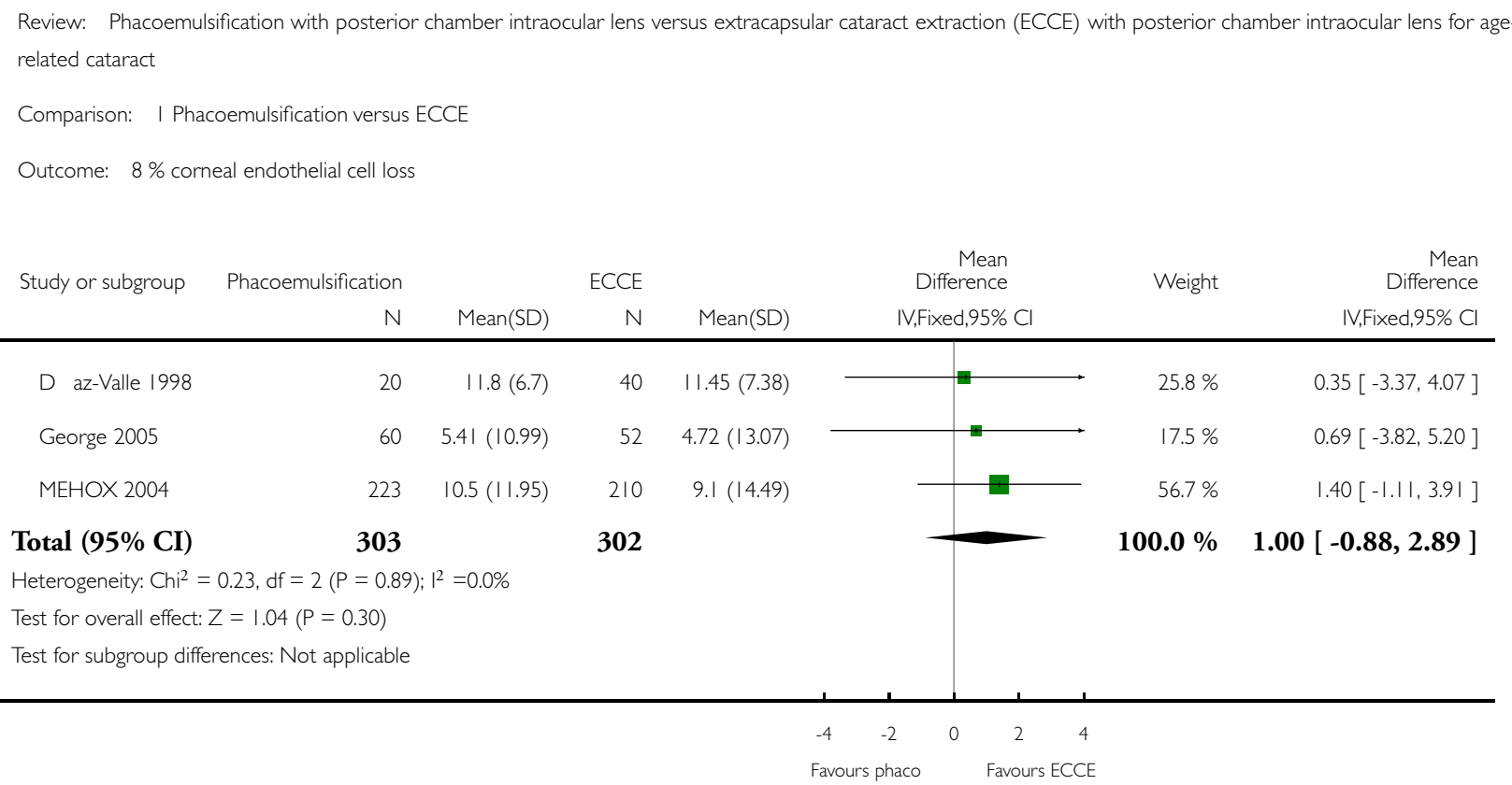

Analysis I.9. Comparison I Phacoemulsification versus ECCE, Outcome 9 Other intraoperative complications.

Other intraoperative complications

\begin{tabular}{lll}
\hline Study & Complication & Result \\
\hline Katsimpris 2004 & Vitreous loss & Phacoemulsification: 2/47 (4\%), ECCE: 8/47 (17\%) \\
\hline Landau 1999 & IOL haptic located in capsular bag & $\begin{array}{l}\text { Phacoemulsification: 18/18 (100\%), ECCE: 10/17 } \\
(59 \%)\end{array}$ \\
\hline MEHOX 2004 & $\begin{array}{l}\text { Choroidal haemorrhage } \\
\text { Iris torn or emulsified } \\
\text { Other "minor" difficulties including: } \\
\text { - anterior chamber collapse or bleed } \\
\text { - anterior capsule tear } \\
\text { - incomplete capsulorhexis }\end{array}$ & $\begin{array}{l}\text { Phacoemulsification: } 1 / 246 \text { (0.4\%), ECCE: } 1 / 236(0 . \\
4 \%) \\
\text { Phacoemulsification: 2/246 (1\%), ECCE: 5/236 (2\%) } \\
\text { Phacoemulsification: 6/246 (2\%), ECCE: 16/236 (7\%) }\end{array}$ \\
\hline
\end{tabular}

Phacoemulsification with posterior chamber intraocular lens versus extracapsular cataract extraction (ECCE) with posterior chamber 


\section{Analysis I.I0. Comparison I Phacoemulsification versus ECCE, Outcome IO Posterior capsule}

opacification.

Review: Phacoemulsification with posterior chamber intraocular lens versus extracapsular cataract extraction (ECCE) with posterior chamber intraocular lens for agerelated cataract

Comparison: I Phacoemulsification versus ECCE

Outcome: 10 Posterior capsule opacification

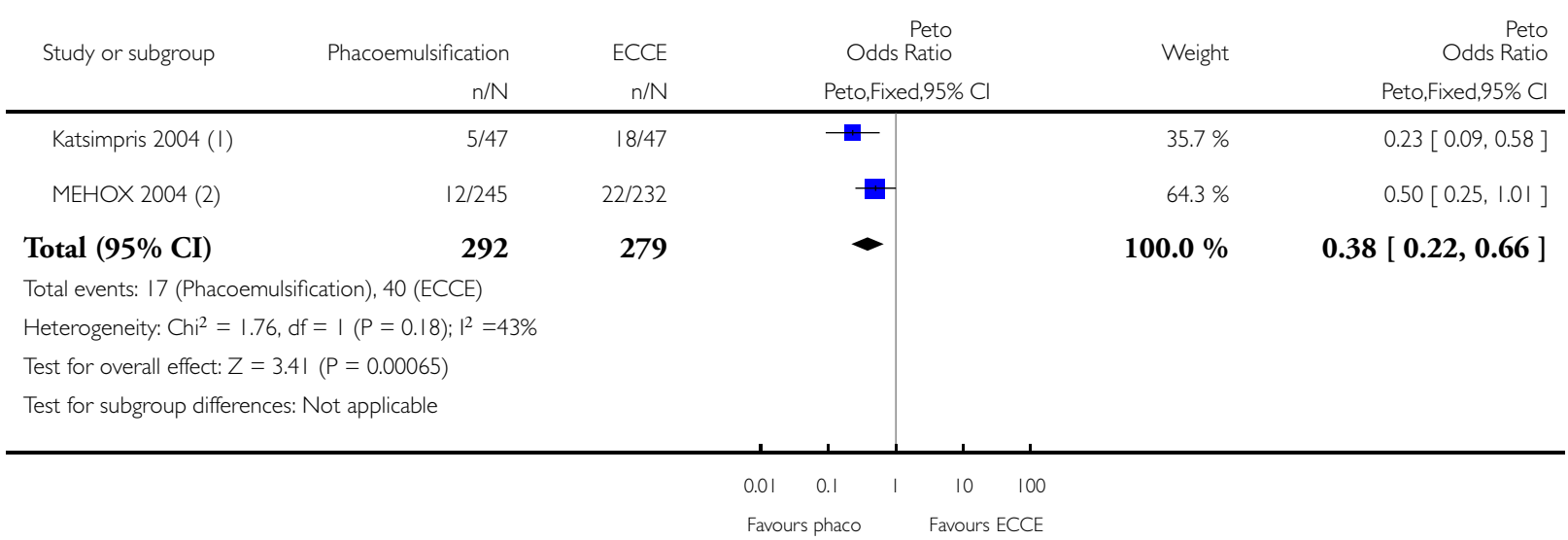

(I) At 14 months

(2) Laser capsulotomy

\section{Analysis I.I I. Comparison I Phacoemulsification versus ECCE, Outcome I I Retinal detachment.}

Review: Phacoemulsification with posterior chamber intraocular lens versus extracapsular cataract extraction (ECCE) with posterior chamber intraocular lens for agerelated cataract

Comparison: I Phacoemulsification versus ECCE

Outcome: II Retinal detachment

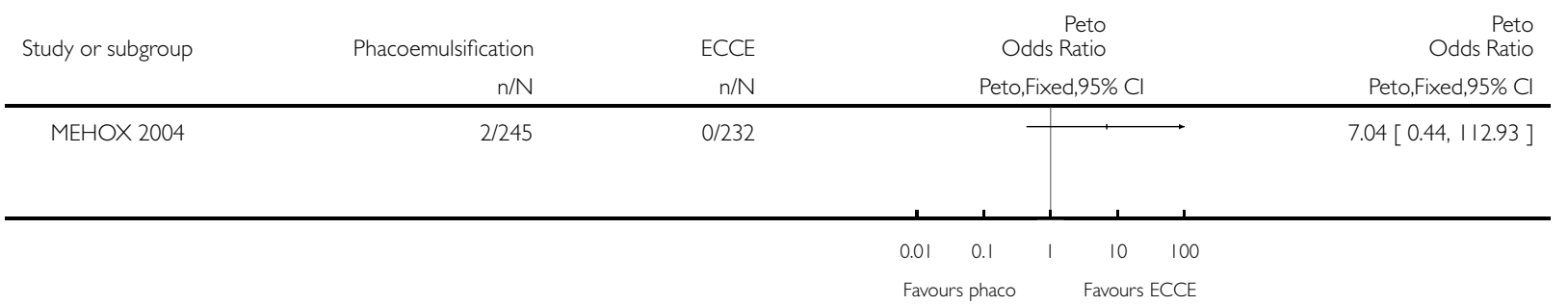

Phacoemulsification with posterior chamber intraocular lens versus extracapsular cataract extraction (ECCE) with posterior chamber 


\section{Analysis I.I2. Comparison I Phacoemulsification versus ECCE, Outcome I2 Cystoid macular oedema.}

Review: Phacoemulsification with posterior chamber intraocular lens versus extracapsular cataract extraction (ECCE) with posterior chamber intraocular lens for agerelated cataract

Comparison: I Phacoemulsification versus ECCE

Outcome: 12 Cystoid macular oedema

\begin{tabular}{|c|c|c|c|c|c|}
\hline Study or subgroup & Phacoemulsification & ECCE & $\begin{array}{r}\text { Peto } \\
\text { Odds Ratio }\end{array}$ & \multirow[t]{2}{*}{ Weight } & $\begin{array}{r}\text { Peto } \\
\text { Odds Ratio }\end{array}$ \\
\hline & $\mathrm{n} / \mathrm{N}$ & $\mathrm{n} / \mathrm{N}$ & Peto,Fixed,95\% Cl & & Peto,Fixed,95\% Cl \\
\hline Katsimpris 2004 & $1 / 47$ & $8 / 47$ & -1 & $62.4 \%$ & $0.18[0.05,0.72]$ \\
\hline MEHOX 2004 & $2 / 245$ & $3 / 232$ & $\longrightarrow$ & $37.6 \%$ & $0.63[0.11,3.68]$ \\
\hline
\end{tabular}

Total $(95 \%$ CI)

292

279

$100.0 \%$

$0.29[0.10,0.86]$

Total events: 3 (Phacoemulsification), I I (ECCE)

Heterogeneity: $\mathrm{Chi}^{2}=1.19, \mathrm{df}=\mathrm{I}(\mathrm{P}=0.27) ; \mathrm{I}^{2}=16 \%$

Test for overall effect: $Z=2.24(P=0.025)$

Test for subgroup differences: Not applicable

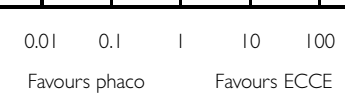

\section{Analysis I.13. Comparison I Phacoemulsification versus ECCE, Outcome I3 Iris prolapse.}

Review: Phacoemulsification with posterior chamber intraocular lens versus extracapsular cataract extraction (ECCE) with posterior chamber intraocular lens for agerelated cataract

Comparison: I Phacoemulsification versus ECCE

Outcome: 13 Iris prolapse

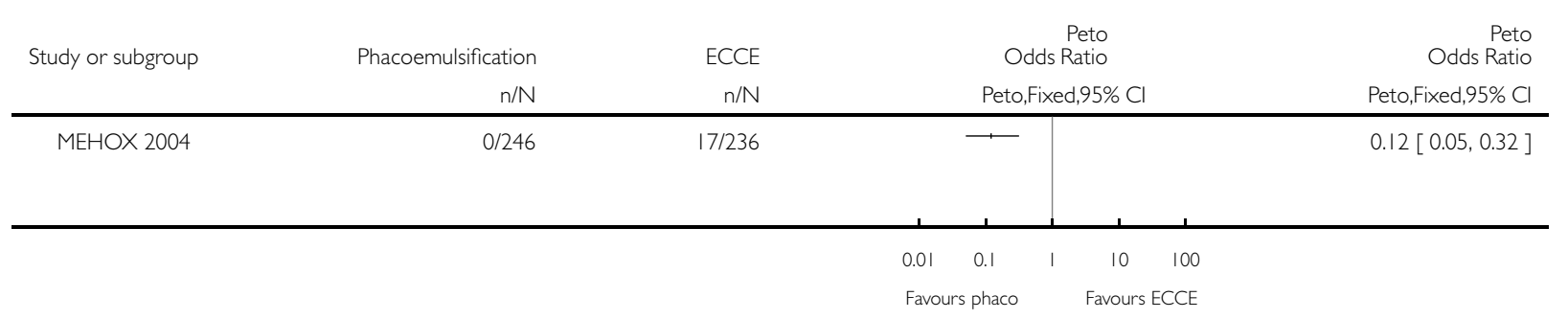

Phacoemulsification with posterior chamber intraocular lens versus extracapsular cataract extraction (ECCE) with posterior chamber 
Analysis I.I4. Comparison I Phacoemulsification versus ECCE, Outcome I4 Other complications. Other complications

\begin{tabular}{|c|c|c|}
\hline Study & Complication & Result \\
\hline Chee 1999 & "Complications" & None reported \\
\hline George 2005 & Mean induced astigmatism in dioptres (SD) & $\begin{array}{l}\text { Phacoemulsification }(\mathrm{n}=60): 0.77(0.65), \text { ECCE }(\mathrm{n}= \\
52): 1.77(1.65)\end{array}$ \\
\hline Katsimpris 2004 & $\begin{array}{l}\text { Corneal oedema (no time point stated) } \\
\text { Transient IOP spike } \\
\text { IOL decentration }\end{array}$ & $\begin{array}{l}\text { Phacoemulsification: 22/47 (47\%), ECCE: } 35 / 47 \\
\text { (74\%) } \\
\text { Phacoemulsification: 4/47 (9\%), ECCE: 14/47 (30\%) } \\
\text { Phacoemulsification: 0/47 (0\%), ECCE: 2/47 (4\%) }\end{array}$ \\
\hline Landau 1999 & Complications & Phacoemulsification: 0/18 (0\%), ECCE: 0/17 (0\%) \\
\hline Laurell 1998 & $\begin{array}{l}\text { Median diffusion coefficient for fluorescein leakage } \\
\text { through the } \mathrm{BAB} \text { at } 3 \text { months }\end{array}$ & $\begin{array}{l}\text { Phacoemulsification }(n=18): 8.58 \text {, ECCE }(n=17): 14 \text {. } \\
34\end{array}$ \\
\hline MEHOX 2004 & Endophthalmitis & $\begin{array}{l}\text { Phacoemulsification: } 3 / 245 \text { (1\%), ECCE: } 1 / 232(0 . \\
4 \%)\end{array}$ \\
\hline
\end{tabular}

\section{ADDITIONAL TABLES}

Table 1. Outcome reporting matrix

\begin{tabular}{|c|c|c|c|c|c|c|c|c|c|c|c|}
\hline & $\begin{array}{l}\text { Chee } \\
1999\end{array}$ & $\begin{array}{l}\text { Diaz- } \\
\text { Valle } \\
1998\end{array}$ & $\begin{array}{l}\text { George } \\
2005\end{array}$ & $\begin{array}{l}\text { Kara- } \\
\text { Junior } \\
2010\end{array}$ & $\begin{array}{l}\text { Katsim- } \\
\text { pris } \\
2004\end{array}$ & $\begin{array}{l}\text { Landau } \\
1999\end{array}$ & $\begin{array}{l}\text { Laurell } \\
1998\end{array}$ & MEHOX & $\begin{array}{l}\text { Raval- } \\
\text { ico } \\
1997\end{array}$ & $\begin{array}{l}\text { Rizal } \\
2003\end{array}$ & $\begin{array}{l}\text { Stumpf } \\
2006\end{array}$ \\
\hline \multicolumn{12}{|l|}{$\begin{array}{l}\text { Review } \\
\text { out- } \\
\text { comes }\end{array}$} \\
\hline $\begin{array}{l}\text { Present- } \\
\text { ing VA } \\
>=6 / 12\end{array}$ & $\sqrt{ }$ & $\mathrm{H}$ & $\mathrm{H}$ & $\mathrm{H}$ & $\mathrm{H}$ & $\mathrm{H}$ & $\mathrm{C}$ & $\sqrt{ }$ & C & $\mathrm{H}$ & $\mathrm{H}$ \\
\hline $\begin{array}{l}\text { BCVA < } \\
6 / 60\end{array}$ & $\mathrm{~F}$ & $\mathrm{H}$ & $\sqrt{ }$ & $\mathrm{H}$ & C & $\mathrm{H}$ & C & $\sqrt{ }$ & C & $\mathrm{H}$ & $\mathrm{C}$ \\
\hline $\begin{array}{l}\text { Capsu- } \\
\text { lar rup- } \\
\text { ture } \\
\text { with } \\
\text { or with- } \\
\text { out vit- }\end{array}$ & $\mathrm{F}$ & $\mathrm{H}$ & $\sqrt{ }$ & $\mathrm{H}$ & $\sqrt{ }$ & $\mathrm{F}$ & $\mathrm{H}$ & $\sqrt{ }$ & $\mathrm{H}$ & $\mathrm{H}$ & $\mathrm{H}$ \\
\hline
\end{tabular}


Table 1. Outcome reporting matrix (Continued)

\begin{tabular}{|c|c|c|c|c|c|c|c|c|c|c|c|}
\hline $\begin{array}{l}\text { reous } \\
\text { loss }\end{array}$ & & & & & & & & & & & \\
\hline $\begin{array}{l}\text { Iris pro- } \\
\text { lapse }\end{array}$ & $\mathrm{F}$ & $\mathrm{H}$ & $\mathrm{H}$ & $\mathrm{H}$ & $\mathrm{H}$ & $\mathrm{F}$ & $\mathrm{H}$ & $\sqrt{ }$ & $\mathrm{H}$ & $\mathrm{H}$ & $\mathrm{H}$ \\
\hline $\begin{array}{l}\text { Postop- } \\
\text { erative } \\
\text { inflam- } \\
\text { mation }\end{array}$ & $\sqrt{ }$ & $\mathrm{H}$ & $\mathrm{H}$ & $\mathrm{H}$ & $\mathrm{H}$ & $\mathrm{H}$ & $\mathrm{H}$ & $\mathrm{H}$ & $\mathrm{H}$ & $\mathrm{H}$ & $\mathrm{H}$ \\
\hline $\begin{array}{l}\text { Poste- } \\
\text { rior cap- } \\
\text { sule } \\
\text { opacifi- } \\
\text { cation }\end{array}$ & $\mathrm{H}$ & $\mathrm{H}$ & $\mathrm{H}$ & $\mathrm{H}$ & $\sqrt{ }$ & $\mathrm{H}$ & $\mathrm{H}$ & $\sqrt{ }$ & $\mathrm{H}$ & $\mathrm{H}$ & $\mathrm{H}$ \\
\hline $\begin{array}{l}\text { Retinal } \\
\text { detach- } \\
\text { ment }\end{array}$ & $\mathrm{H}$ & $\mathrm{H}$ & $\mathrm{H}$ & $\mathrm{H}$ & $\mathrm{H}$ & $\mathrm{H}$ & $\mathrm{H}$ & $\sqrt{ }$ & $\mathrm{H}$ & $\mathrm{H}$ & $\mathrm{H}$ \\
\hline $\begin{array}{l}\text { Glau- } \\
\text { coma }\end{array}$ & $\mathrm{H}$ & $\mathrm{H}$ & $\mathrm{H}$ & $\mathrm{H}$ & $\mathrm{H}$ & $\mathrm{H}$ & $\mathrm{H}$ & & $\mathrm{H}$ & $\mathrm{H}$ & $\mathrm{H}$ \\
\hline $\begin{array}{l}\text { Cystoid } \\
\text { macular } \\
\text { oedema }\end{array}$ & $\mathrm{H}$ & $\mathrm{H}$ & $\mathrm{H}$ & $\mathrm{H}$ & $\sqrt{ }$ & $\mathrm{H}$ & $\mathrm{H}$ & $\sqrt{ }$ & $\mathrm{H}$ & $\mathrm{H}$ & $\mathrm{H}$ \\
\hline $\begin{array}{l}\text { Corneal } \\
\text { en- } \\
\text { dothelial } \\
\text { cell loss }\end{array}$ & $\mathrm{H}$ & $\sqrt{ }$ & $\sqrt{ }$ & $\mathrm{H}$ & $\mathrm{H}$ & $\mathrm{H}$ & $\mathrm{H}$ & $\sqrt{ }$ & $\mathrm{H}$ & $\mathrm{H}$ & $\mathrm{H}$ \\
\hline $\begin{array}{l}\text { Corneal } \\
\text { decom- } \\
\text { pensa- } \\
\text { tion }\end{array}$ & $\mathrm{H}$ & $\mathrm{H}$ & $\mathrm{H}$ & $\mathrm{H}$ & $\mathrm{H}$ & $\mathrm{H}$ & $\mathrm{H}$ & $\mathrm{H}$ & $\mathrm{H}$ & $\mathrm{H}$ & $\mathrm{H}$ \\
\hline $\begin{array}{l}\text { Quality } \\
\text { of life }\end{array}$ & I & I & I & $\sqrt{ }$ & I & I & I & I & I & I & I \\
\hline $\begin{array}{l}\text { Other } \\
\text { out- } \\
\text { comes } \\
\text { (list } \\
\text { other } \\
\text { out- } \\
\text { comes } \\
\text { re- } \\
\text { ported) }\end{array}$ & & $\begin{array}{l}\text { Change } \\
\text { in } \\
\text { corneal } \\
\text { thick- } \\
\text { ness }\end{array}$ & $\begin{array}{l}\text { Mean } \\
\text { induced } \\
\text { astigma- } \\
\text { tism }\end{array}$ & $\begin{array}{l}\text { Cost, } \\
\text { number } \\
\text { of days } \\
\text { off work }\end{array}$ & $\begin{array}{l}\text { Zonular } \\
\text { dialysis, } \\
\text { corneal } \\
\text { oedema, } \\
\text { transient } \\
\text { IOP } \\
\text { spike, } \\
\text { IOL de- } \\
\text { centra- }\end{array}$ & $\begin{array}{l}\text { IOL } \\
\text { haptic } \\
\text { located } \\
\text { in capsu- } \\
\text { lar bag, } \\
\text { "compli- } \\
\text { cations" }\end{array}$ & $\begin{array}{l}\text { Operat- } \\
\text { ing time, } \\
\text { corneal } \\
\text { thick- } \\
\text { ness, dif- } \\
\text { fu- } \\
\text { sion co- } \\
\text { efficient }\end{array}$ & $\begin{array}{l}\text { Choroidal } \\
\text { haemor- } \\
\text { rhage, } \\
\text { endoph- } \\
\text { thalmi- } \\
\text { tis, other } \\
\text { "minor" }\end{array}$ & $\begin{array}{l}\text { Corneal } \\
\text { thick- } \\
\text { ness }\end{array}$ & $\begin{array}{l}\text { Opera- } \\
\text { tion } \\
\text { time, } \\
\text { cost }\end{array}$ & $\begin{array}{l}\text { Opera- } \\
\text { tion } \\
\text { time, } \\
\text { corneal } \\
\text { thick- } \\
\text { ness }\end{array}$ \\
\hline
\end{tabular}

Phacoemulsification with posterior chamber intraocular lens versus extracapsular cataract extraction (ECCE) with posterior chamber 
Table 1. Outcome reporting matrix (Continued)

\begin{tabular}{|l|l|l|}
\hline tion & $\begin{array}{l}\text { for fluo- difficul- } \\
\text { rescein } \\
\text { leakage } \\
\text { through }\end{array}$ \\
& BAB cost \\
\hline
\end{tabular}

$\sqrt{ }$ Reported and included in review.

Other codes see Appendix 9.

BAB: blood-aqueous barrier

BCVA: best corrected visual acuity

IOL: intraocular lens

VA: visual acuity

Table 2. Corneal thickness

\begin{tabular}{|c|c|c|}
\hline Díaz-Valle 1998 & $\begin{array}{l}\text { Mean change in corneal thickness }(\mu \mathrm{m}) \\
\text { - at } 3 \text { months }\end{array}$ & $\begin{array}{l}\text { Phacoemulsification }(n=20): 5 \text { ECCE }(n=20 \text { CCC, } n \\
=20 \text { letterbox } 24 \text { and } 15\end{array}$ \\
\hline Laurell 1998 & $\begin{array}{l}\text { Mean increase in corneal thickness }(\mu \mathrm{m}) \\
\text { - at day } 3\end{array}$ & Phacoemulsification $(\mathrm{n}=20): 29$ ECCE $(\mathrm{n}=20): 29$ \\
\hline Laurell 1998 & $\begin{array}{l}\text { Mean increase in corneal thickness }(\mu \mathrm{m}) \\
-3 \text { months }\end{array}$ & Phacoemulsification $(n=19):-4$ ECCE $(n=20): 3$ \\
\hline Ravalico 1997 & $\begin{array}{l}\text { Corneal thickness ( } \% \text { increase) } \\
\text { - at } 7 \text { days }\end{array}$ & Phacoemulsification $(n=20): 2.1$ ECCE $(n=20): 6.4$ \\
\hline Ravalico 1997 & $\begin{array}{l}\text { Corneal thickness ( } \% \text { increase) } \\
\text { - at } 30 \text { days }\end{array}$ & Phacoemulsification $(n=20) 0.8:$ ECCE $(n=20): 4.8$ \\
\hline Ravalico 1997 & $\begin{array}{l}\text { Mean }(\mathrm{SD}) \text { change in corneal thickness } \\
\text { - at } 7 \text { days }\end{array}$ & $\begin{array}{l}\text { Phacoemulsification }(n=20) 11.6(10.5): \text { ECCE }(n= \\
20): 34.7(12.5)\end{array}$ \\
\hline Ravalico 1997 & $\begin{array}{l}\text { Mean }(\mathrm{SD}) \text { change in corneal thickness } \\
\text { - at } 30 \text { days }\end{array}$ & $\begin{array}{l}\text { Phacoemulsification }(n=20) 4.7(10.3): \text { ECCE }(n=20) \\
: 26.3(12.2)\end{array}$ \\
\hline Stumpf 2006 & $\begin{array}{l}\text { Mean corneal thickness increase } \\
-1 \text { month }\end{array}$ & Phacoemulsification $(\mathrm{n}=20): 7$ ECCE $(\mathrm{n}=21): 7$ \\
\hline Stumpf 2006 & $\begin{array}{l}\text { Mean corneal thickness increase } \\
-3 \text { months from baseline }\end{array}$ & Phacoemulsification $(\mathrm{n}=20): 0$ ECCE $(\mathrm{n}=21): 1$ \\
\hline Stumpf 2006 & $\begin{array}{l}\text { Mean corneal thickness increase } \\
-6 \text { months from baseline }\end{array}$ & Phacoemulsification $(\mathrm{n}=20): 3$ ECCE $(\mathrm{n}=21): 5$ \\
\hline
\end{tabular}

Phacoemulsification with posterior chamber intraocular lens versus extracapsular cataract extraction (ECCE) with posterior chamber 


\section{A P P E N D I C E S}

\section{Appendix I. CENTRAL search strategy}

\#1 MeSH descriptor Cataract

\#2 MeSH descriptor Cataract Extraction

\#3 MeSH descriptor Lens, Crystalline

\#4 MeSH descriptor Lenses, Intraocular

\#5 MeSH descriptor Lens Implantation, Intraocular

\#6 intraocular lens* or intra ocular lens* or IOL*

\#7 (\#1 OR \#2 OR \#3 OR \#4 OR \#5 OR \#6)

\#8 MeSH descriptor Phacoemulsification

\#9 pha?oemulsif*

\#10 phaco or phako

\#11 (\#8 OR \#9 OR \#10)

\#12 extracapsular near/2 cataract

\#13 extra capsular near/2 cataract

\#14 ECCE

\#15 (\#12 OR \#13 OR \#14)

\#16 (\#7 AND \#11 AND \#15)

\section{Appendix 2. MEDLINE (OvidSP) search strategy}

1. randomized controlled trial.pt.

2. (randomized or randomised).ab,ti.

3. placebo.ab,ti.

4. dt.fs.

5. randomly.ab,ti.

6. trial.ab,ti.

7. groups.ab,ti.

8. or/1-7

9. exp animals/

10. exp humans/

11. 9 not (9 and 10)

12. 8 not 11

13. exp cataract/

14. cataract extraction/

15. exp lens crystalline/

16. exp lenses intraocular/

17. lens implantation intraocular/

18. (intraocular lens\$ or intra ocular lens\$ or IOL\$).tw.

19. or/13-18

20. phacoemulsification/

21. pha?oemulsif\$.tw.

22. (phaco or phako).tw.

23. or/20-22

24. (extracapsular adj2 cataract\$).tw.

25. (extra capsular adj2 cataract\$).tw.

26. ECCE.tw.

27. or/ $24-26$

28. 19 and 23 and 27

29. 12 and 28

The search filter for trials at the beginning of the MEDLINE strategy is from the published paper by Glanville et al (Glanville 2006).

Phacoemulsification with posterior chamber intraocular lens versus extracapsular cataract extraction (ECCE) with posterior chamber intraocular lens for age-related cataract (Review)

Copyright $\odot 2014$ The Cochrane Collaboration. Published by John Wiley \& Sons, Ltd. 


\section{Appendix 3. EMBASE.com search strategy}

1. exp randomized controlled trial/

2. exp randomization/

3. exp double blind procedure/

4. exp single blind procedure/

5. random $\$$.tw.

6. or/1-5

7. (animal or animal experiment).sh.

8. human.sh.

9.7 and 8

10. 7 not 9

11. 6 not 10

12. exp clinical trial/

13. (clin\$ adj3 trial\$).tw.

14. ((singl\$ or doubl $\$$ or trebl $\$$ or tripl $\$$ ) adj3 (blind $\$$ or mask $\$)$ ).tw.

15. exp placebo/

16. placebo $\$ . t w$.

17. random $\$$.tw.

18. exp experimental design/

19. exp crossover procedure/

20. exp control group/

21. exp latin square design/

22. or/ $12-21$

23. 22 not 10

24. 23 not 11

25. exp comparative study/

26. exp evaluation/

27. exp prospective study/

28. (control\$ or prospectiv $\$$ or volunteer $\$$ ).tw.

29. or $/ 25-28$

30. 29 not 10

31.30 not (11 or 23$)$

32. 11 or 24 or 31

33. exp cataract/

34. exp cataract extraction/

35. exp lens/

36. exp lens implant/

37. exp lens implantation/

38. (intraocular lens $\$$ or intra ocular lens $\$$ or IOLS).tw.

39. or/33-38

40. exp phacoemulsification/

41. pha?oemulsif\$.tw.

42. (phaco or phako).tw.

43. or $/ 40-42$

44. exp extracapsular cataract extraction/

45. (extracapsular adj2 cataract\$).tw.

46. (extra capsular adj2 cataract\$).tw.

47. ECCE.tw.

48. or/44-47

49. 39 and 43 and 48

50.32 and 49

Phacoemulsification with posterior chamber intraocular lens versus extracapsular cataract extraction (ECCE) with posterior chamber 


\section{Appendix 4. LILACS search strategy}

cataract $\$$ and phaco $\$$ or phako $\$$ and extracapsular or extra capsular or ECCE

\section{Appendix 5. Web of Science CPCI-S search strategy}

$\# 8$ \#3 and \#6 and \#7

$\# 7 \mathrm{TS}=$ (extracapsular or extra capsular or ECCE)

\#6 \#4 or \#5

\#5 TS=(phaco or phako)

\#4 TS=(phacoemulsification or phakoemulsification)

\#3 \#1 OR \#2

\#2 TS=(intraocular lens* or intra ocular lens* or $\mathrm{IOL}^{*}$ )

\#1 TS=cataract*

\section{Appendix 6. metaRegister of Controlled Trials search strategy}

cataract AND phacoemulsification

\section{Appendix 7. ClinicalTrials.gov search strategy}

cataract AND phacoemulsification

\section{Appendix 8. ICTRP search strategy}

phacoemulsification $=$ Condition AND extracapsular or extra capsular or ECCE $=$ Intervention

\section{Appendix 9. ORBIT classification}

The Outcome Reporting Bias In Trials (ORBIT) study classification system for missing or incomplete outcome reporting in reports of randomised trials as given in Kirkham 2010.

\begin{tabular}{l|l|l}
\hline Description & Level of reporting & Risk of bias \\
\hline Clear that the outcome was measured and analysed & High risk \\
\hline A & $\begin{array}{l}\text { Trial report states that outcome was } \\
\text { analysed but only reports that result } \\
\text { was not significant (typically stating P } \\
>0.05)\end{array}$ & No risk \\
\hline B & $\begin{array}{l}\text { Trial report states that outcome was } \\
\text { analysed but only reports that result } \\
\text { was significant (typically stating P }< \\
0.05)\end{array}$ & \\
\hline
\end{tabular}

Phacoemulsification with posterior chamber intraocular lens versus extracapsular cataract extraction (ECCE) with posterior chamber 


\begin{tabular}{l|l|l}
\hline C & $\begin{array}{l}\text { Trial report states that outcome was } \\
\text { analysed but insufficient data were } \\
\text { presented for the trial to be included } \\
\text { in meta-analysis or to be considered } \\
\text { to be fully tabulated }\end{array}$ & Low risk \\
\hline D & $\begin{array}{l}\text { Trial report states that outcome was } \\
\text { analysed but no results reported }\end{array}$ & None High risk \\
\hline
\end{tabular}

\section{Clear that the outcome was measured}

\begin{tabular}{l|l|l|l|}
\hline E & $\begin{array}{l}\text { Clear that outcome was measured but } \\
\text { not necessarily analysed. Judgement } \\
\text { says likely to have been analysed but } \\
\text { not reported because of non-signifi- } \\
\text { cant results }\end{array}$ & High risk \\
\hline F & $\begin{array}{l}\text { Clear that outcome was measured but } \\
\text { not necessarily analysed. Judgement } \\
\text { says unlikely to have been analysed } \\
\text { but not reported because of non-sig- } \\
\text { nificant results }\end{array}$ & Low risk \\
\hline
\end{tabular}

Unclear whether the outcome was measured

\begin{tabular}{l|l|l|l}
\hline G & $\begin{array}{l}\text { Not mentioned but clinical judge- } \\
\text { ment says likely to have been mea- } \\
\text { sured and analysed but not reported } \\
\text { on the basis of non-significant results }\end{array}$ & High risk \\
\hline $\mathrm{H}$ & $\begin{array}{l}\text { Not mentioned but clinical judge- } \\
\text { ment says unlikely to have been mea- } \\
\text { sured at all }\end{array}$ & Low risk \\
\hline
\end{tabular}

\section{Clear that the outcome was not measured}

$\begin{array}{llll}\text { I Clear that outcome was not measured NA N N } & \text { No risk }\end{array}$

\section{CONTRIBUTIONSOFAUTHORS}

Conceiving the review: YR

Designing the review: YR, JE

Co-ordinating the review: YR, JE

Phacoemulsification with posterior chamber intraocular lens versus extracapsular cataract extraction (ECCE) with posterior chamber 
Data collection for the review:

- Designing electronic search strategies: Cochrane Eyes and Vision Group editorial base

- Undertaking manual searches: YR

- Screening search results: YR, SdeS

- Organising retrieval of papers: YR

- Screening retrieved papers against inclusion criteria: YR, SdeS

- Appraising quality of papers: YR, JE, SdeS

- Extracting data from papers: YR, JE, SdeS

- Writing to authors of papers for additional information: YR, SdeS

- Obtaining and screening data on unpublished studies: YR

Data management for the review:

- Entering data into RevMan: YR, SdeS

Analysis of data: YR, JE, SdeS

Interpretation of data:

- Providing a methodological perspective: JE

- Providing a clinical perspective: YR, SdeS

- Providing a policy perspective: YR, SdeS

Writing the review: YR, JE, SdeS

Performing previous work that was the foundation of the current study: YR, JE

\section{DECLARATIONSOF INTEREST}

None known.

\section{SOURCES OF SUPPORT}

\section{Internal sources}

- No sources of support supplied 


\section{External sources}

- Sightsavers, UK.

\section{DIFFERENCES BETWEEN PROTOCOLANDREVIEW}

The primary visual acuity (VA) outcomes for this review were presenting VA of 6/12 or better, or a best corrected VA of worse than 6/ 60. None of the papers documented presenting VA, and therefore we report both uncorrected and best-corrected VA.

\section{NOTES}

The original published Cochrane review 'Riaz Y, Mehta JS, Wormald R, Evans JR, Foster A, Ravilla T, Snellingen T. Surgical interventions for age-related cataract. Cochrane Database of Systematic Reviews 2006, Issue 4. Art. No.: CD001323. DOI: 10.1002/ 14651858.CD001323.pub2' has been divided into three smaller reviews each using the same outcome measures as the original review but only comparing two surgical methods within each review. The interventions being compared are ECCE, MSICS and phacoemulsification. Intracapsular extraction (ICCE) is no longer included in the reviews as this technique is no longer used as a primary procedure.

\section{INDEX TERMS}

\section{Medical Subject Headings (MeSH)}

*Lenses, Intraocular; Cataract Extraction [adverse effects; *methods]; Clinical Protocols; Phacoemulsification [adverse effects; *methods]; Posterior Eye Segment [injuries]; Randomized Controlled Trials as Topic

\section{MeSH check words}

Aged; Aged, 80 and over; Humans; Middle Aged 